\title{
11
}

\section{Real-time ultrasound (RTU) imaging methods for quality control of meats}

\author{
S. R. Silva, CECAV, University of Trás-os-Montes e Alto Douro, \\ Portugal and V. P. Cadavez, CIMO, ESA, Instituto Politécnico de \\ Bragança, Portugal
}

\begin{abstract}
In this chapter the use of real-time ultrasonography to predict in vivo carcass composition and meat traits will be reviewed. The chapter begins by discussing background and principles of ultrasound. Then aspects affecting the suitability of realtime ultrasonography and image analysis for predicting carcass composition and meat traits of meat producing species and fish will be presented. This chapter also provides an overview of the present and future trends in the application of real-time ultrasonography in the meat industry.
\end{abstract}

Key words: meat quality, ultrasound, carcass, image analysis.

\subsection{Introduction}

Carcass composition and meat traits are important aspects of animal science relating to food production. This knowledge is fundamental to the study of genetics, nutrition, physiology, to marketing based on carcass value, as well as for monitoring body fat reserves. Dissection and chemical analysis have traditionally been used as the standard methods for determining carcass composition. However, these procedures are expensive, laborious and destructive (i.e., an animal or carcass can be used only once). Non-destructive techniques are often required to test valuable animals or when sequential study of the animals is necessary or desirable (Fuller et al., 1990). The search for non-destructive methods of estimating carcass composition or meat traits has led to the evaluation of numerous techniques such as real-time ultrasound (RTU), computer tomography (CT), magnetic resonance 
imaging (MRI), dual-energy X-ray absorptiometry (DXA), whole-body ${ }^{40} \mathrm{~K}$ counting, total body electrical conductivity (TOBEC), dilution techniques, bioelectrical impedance and neutron activation analysis. These techniques have been reviewed by several researchers, including Allen (1990), Fuller et al. (1994), Stanford et al. (1998), Szabo et al. (1999), De Campeneere et al. (2000), Mitchell and Scholz (2005) and Teixeira (2009). Of the techniques mentioned above, only those based on RTU will be outlined in this chapter. Techniques based on ultrasound have had great success in the fields of medical and animal science, as they are noninvasive, non-destructive and do not cause pain to the animal. For over 50 years, ultrasound techniques have been used to predict carcass composition and meat traits in vivo. Since its initial use, and especially in the last two decades, RTU has been demonstrated to be a valuable tool for the estimation of carcass composition and meat traits in living animals. The recent interest in the technique is almost certainly a result of the application of technology originally developed for computers, whereby a digital image formation process provides good quality black and white images. Furthermore, modern equipment is robust, easy to use and portable, and offers accurate imaging with great repeatability at relatively low cost, while also being well accepted by the public (Allen, 1990; Stanford et al., 1998). This chapter presents an overview of the use of RTU in predicting carcass composition and meat traits in meat-producing species and fish.

\subsection{Historical background on ultrasound use for carcass composition and meat traits evaluation}

The roots of the use of ultrasound techniques for animal science purposes can be identified in several discoveries throughout history and are closely connected to the same developments in the medical field. The discovery of the piezoelectric properties of certain crystals in 1880 by the Curie brothers is one major milestone in the development of ultrasound (Woo, 2006) (Table 11.1). Since then, the applications of ultrasound have expanded rapidly in the fields of navigation, medicine (Thwaites, 1984; Szabo, 2004) and non-destructive testing in industry (Bray and McBride, 1992; Chen, 2007).

Mankind has always had a fascination with the idea that it might be possible to look inside objects and, with sonar and radar as models, it was established that pulse-echo techniques had the potential to be used for medical purposes (Szabo, 2004). After five years of work on ultrasound principles and equipment development, the first diagnostic ultrasound study was published (Dussik, 1942). Some years later, Wild (1950) presented the first use of ultrasonic pulses for the measurement of biological tissues and the detection of tissue density with ultrasound equipment. This equipment contained a transducer that sent a sequence of repetitive ultrasonic pulses into a material or a body (Wells, 1991; Whittaker et al., 1992). Echoes from different target objects and boundaries were received and amplified so that they could be displayed on an oscilloscope as an amplitudeversus-time record (Thwaites, 1984; Wells, 1991; Whittaker et al., 1992). This 
Table 11.1 Milestones for ultrasound development and application in animal science

\begin{tabular}{|c|c|c|c|c|}
\hline $\begin{array}{l}\text { Discovery or } \\
\text { application }\end{array}$ & Year & Author & Description & Reference \\
\hline Eco-localization & 1790 & $\begin{array}{l}\text { Lazzaro } \\
\quad \text { Spallanzani }\end{array}$ & $\begin{array}{l}\text { In } 1790 \text { Lazzaro Spallanzani experimented with bats and } \\
\text { found that they manoeuvred through the air using their } \\
\text { hearing rather than sight }\end{array}$ & Kane et al. (2004) \\
\hline $\begin{array}{l}\text { Piezoelectric } \\
\text { proprieties }\end{array}$ & 1881 & Pierre Curie & $\begin{array}{l}\text { In } 1881 \text { Pierre Curie found a connection between electrical } \\
\text { voltage and pressure on crystalline material. This was } \\
\text { the breakthrough that was needed to create the modern } \\
\text { ultrasound transducer }\end{array}$ & Turner et al. (1994) \\
\hline $\begin{array}{l}\text { Using ultrasound in } \\
\text { submarine warfare }\end{array}$ & 1916 & & $\begin{array}{l}\text { The first recorded detection and subsequent sinking of a } \\
\text { German U-boat (UC-3) using a hydrophone }\end{array}$ & Kane et al. (2004) \\
\hline $\begin{array}{l}\text { First report of } \\
\text { ultrasound use for } \\
\text { medical purposes }\end{array}$ & 1942 & Karl Dussik & $\begin{array}{l}\text { Karl and Friederich Dussik used the first medical application } \\
\text { of ultrasound when they localized brain tumours by } \\
\text { measuring the sound transmission through the skull and } \\
\text { brain }\end{array}$ & Weinstein et al. (2006) \\
\hline $\begin{array}{l}\text { Ultrasound propagation } \\
\text { speed in body tissues }\end{array}$ & 1950 & Ludwig & $\begin{array}{l}\text { Ludwig (1950) made a number of time-of-flight } \\
\text { measurements of sound speed through arm, leg, and thigh } \\
\text { muscles. He found the average to be } 1540 \mathrm{~ms}^{-1} \text {, which is } \\
\text { the standard value still used today }\end{array}$ & Ludwig (1950) \\
\hline $\begin{array}{l}\text { First article showing } \\
\text { the utility of } \\
\text { ultrasounds for soft } \\
\text { tissues }\end{array}$ & 1950 & Wild & $\begin{array}{l}\text { The first scientific proof of sonic energy reflection from } \\
\text { within soft tissue histological elements, using 'A' mode } \\
\text { readout }\end{array}$ & Wild (1950) \\
\hline First B-mode & 1952 & Wild and Reid & $\begin{array}{l}\text { The B-mode scanner became one of the first to differentiate } \\
\text { between abnormal tissue }\end{array}$ & Wild and Reid (1952) \\
\hline $\begin{array}{l}\text { First animal evaluation } \\
\text { publication using } \\
\text { ultrasounds }\end{array}$ & 1956 & Temple et al. & $\begin{array}{l}\text { First ultrasound animal evaluation publication in the United } \\
\text { States }\end{array}$ & Temple et al. (1956) \\
\hline
\end{tabular}


Table 11.1 Continued

\begin{tabular}{|c|c|c|c|c|}
\hline $\begin{array}{l}\text { Discovery or } \\
\text { application }\end{array}$ & Year & Author & Description & Reference \\
\hline $\begin{array}{l}\text { First B-mode study } \\
\text { with animals }\end{array}$ & 1959 & Stouffer & $\begin{array}{l}\text { Cross-sectional image of beef rib eye produced by an early } \\
\text { mechanical B-scan system improved by mounting the } \\
\text { transducer on a carriage that moved along a fixed, shaped, } \\
\text { curved guide }\end{array}$ & Stouffer et al. (1959) \\
\hline A reference study & 1961 & Stouffer & $\begin{array}{l}\text { Study with hogs, cattle and sheep showing the superior } \\
\text { performance of mechanical B-scan over the A-mode }\end{array}$ & Stouffer et al. (1961) \\
\hline First real time & 1965 & & $\begin{array}{l}\text { Appearance of Vidoson from Siemens, the first real-time } \\
\text { mechanical commercial scanner }\end{array}$ & Szabo (2004) \\
\hline Scanogram & 1969 & Stouffer & $\begin{array}{l}\text { Scanogram, commercial mechanical B-scanner, second } \\
\text { generation, produced by Ithaco Inc, } 1969\end{array}$ & Stouffer (2004) \\
\hline $\begin{array}{l}\text { First RTU application } \\
\text { for carcass traits } \\
\text { evaluation }\end{array}$ & 1976 & Hans Busk & $\begin{array}{l}\text { Use of the RTU Danscanner in breeding programmes for pigs, } \\
\text { cattle and sheep }\end{array}$ & Busk (1984) \\
\hline First 3-D & 1987 & & First 3-D ultrasound & Szabo (2004) \\
\hline
\end{tabular}


type of display became known as the A-mode, with A standing for amplitude (Szabo, 2004). The distances between successive peaks represent the thickness of the different tissues. In animal science, the horizontal axis of the oscilloscope is calibrated in millimetres, allowing for a direct reading.

After the first medical applications, this ultrasound technique was immediately recognized as a potential tool for animal science, as shown by the work published in the late 1950s on animal carcass evaluation (Stouffer, 2004). These publications reported research results showing the feasibility of using ultrasound to evaluate carcass composition in live cattle (Temple et al., 1956), swine (Claus, 1957; Dumont, 1957; Hazel and Kline, 1959) and sheep (Campbell et al., 1959).

Despite the encouraging findings, the accuracy of the early A-mode, a single-transducer device, was often quite variable (Stouffer, 2004). Moreover, the A-mode display has limited use, because it lacks anatomical information, meaning that it is difficult to identify the anatomical sources of the echoes (Ophir and Maklad, 1979), and that it is impossible to trace area measurements from images of organs or tissues (Thwaites, 1984). To overcome these limitations, the B-mode presentation (' $\mathrm{B}$ ' meaning brightness) was introduced. B-mode is an image display created by integrating multiple A-mode signals (Amin, 1995). In B-mode, the brightness of the dots is proportional to the amplitude of the echoes. The display consists of time traces running vertically (top to bottom) to indicate depth.

By the early 1960s a pioneering technique in the use of ultrasound for animal science purposes was introduced: a continuous mechanical scanning procedure (Stouffer et al., 1961). An electric motor was mounted on a thick rubber belt that was placed on the animal's back. The motor moved a transducer horizontally as it was held vertically by an operator, and was synchronized to keep the lens open for the duration of the $10 \mathrm{~s}$ scan in order to capture the image. The image on Polaroid film was developed in about $1 \mathrm{~min}$, and the image data was then evaluated and measured. In the same period, the first commercialized contact B-mode mechanical scanners became available for medical purposes (Szabo, 2004). At the end of the $1960 \mathrm{~s}$, a commercial unit of the primary system was introduced for live animal evaluation, using similar technology (Stouffer, 2004). This equipment - the Scanogram - produced in 1969 by Ithaco Inc. (Ithaca, NY), was in use until the mid-1980s for the majority of in vivo carcass evaluation studies using ultrasound (Miles et al., 1972; Shelton et al., 1977; Kempster et al., 1982; Andersen et al., 1983; Simm et al., 1983). However, one of the major limitations of B-mode mechanical scanners for animal applications was the movement of the animal, which, being random, was the cause of inaccuracy of images and low repeatability of measurements (Hedrick et al., 1962; Gooden et al., 1980; Stouffer, 2004).

The launch of RTU systems with good image quality marked the end of the mechanical B-scanners, which had completely disappeared by the late 1980s (Klein, 1981; Szabo, 2004). RTU systems are based on the B-mode technique, and use multiple-crystal transducers to display an image on the screen that is constantly updated. The entire image frame must be displayed in $33 \mathrm{~ms}$ or less in order to be able to update the information at real-time frame rates (Insana, 2006). 


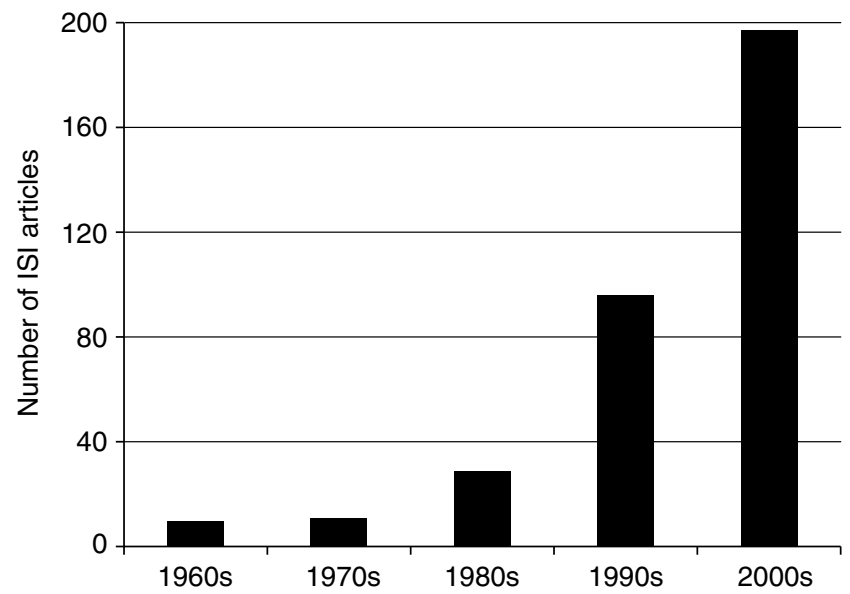

Fig. 11.1 Number of articles in main animal science journals (ISI indexed) using ultrasound to evaluate carcass traits.

RTU reduces the time required to produce and record an image, which greatly enhances the use of this technique in live animal evaluation.

Since the first attempts to image carcass traits using the RTU technique in the late 1970s (Kempster et al., 1979) and early 1980s (Kempster et al., 1982), significant advances in hardware and software have allowed the initial obstacles - animal movement and long acquisition times - to be overcome. In recent years, RTU has become a crucial tool in many routine carcass evaluations for animal production, and offers the advantage of providing data not only on carcass traits but also on a multitude of meat and fat deposits, which are similar to or even superior to those provided by more expensive imaging tools. The features of the ultrasound equipment, combined with the possibility of differentiating tissues and organs in the image, form the basis of the huge success that this technique has achieved in medicine and in animal science.

There has been a radical increase in the use of RTU imaging in animal science in the last 20 years, due to significant technological improvements and the availability of more accurate and less costly equipment. During this period, RTU has been widely used in the prediction of carcass traits, as shown by the numerous works found in the major animal science journals (Fig. 11.1).

\subsection{Basic ultrasound imaging principles}

Ultrasound is sound waves that have a frequency beyond the range of human hearing (above $20 \mathrm{kHz}$ ). These acoustic waves propagate through body tissues via compression and expansion of the tissues, and during propagation small particles of the material move back and forth in order to generate the compressions and expansions of the acoustic wave (Mannion, 2006). In soft tissues (biological 
tissue), these particles move back and forth in the same direction that the acoustic wave is travelling (Prince and Links, 2006). The particles themselves merely oscillate or are displaced locally; it is the wave that travels from source to detector, not the particles (Leighton, 2007). The ultrasonic waves have different propagation properties and can be characterized by the following formula

$$
v=f \lambda
$$

where $\lambda$ is the wavelength, $f$ is frequency and $v$ is velocity. The acoustic impedance $Z$ is a fundamental property of the tissue and is related to the density $\rho$ and the velocity

$$
Z=\rho v
$$

The fraction of energy reflected, $R$, at the normal interface of two different tissue types is

$$
R=\left(\frac{Z_{2}-Z_{1}}{Z_{2}+Z_{1}}\right)^{2}
$$

where $Z_{1}$ and $Z_{2}$ are the impedance of the tissues in the interface (Seidband, 1998). The acoustic signals decrease as a result of attenuation by the medium, and the signal intensity $I$ is given by

$$
I=\frac{I o e^{-\alpha r}}{r^{2}}
$$

where $\alpha$ is the coefficient of attenuation, $I_{0}$ is the incident signal intensity and $r$ is the distance (Seidband, 1998). Most biological tissues have high coefficients of attenuation, which increases as frequency increases (Seidband, 1998). Thus, it is important to establish the thickness of the tissue at which the attenuation of the medium decreases the signal by half (half-value layer, HVL) (Seidband, 1998). Ultrasound of higher frequencies provides higher resolution, yet the increased HVL reduces the depth of penetration. The acoustic properties of some tissues at 1.0 MHz are presented in Table 11.2.

In soft tissues, the ultrasound waves propagate at a velocity of about 1500 $\mathrm{m} / \mathrm{s}$. Each change of tissue type causes a reflection and the greater the difference in acoustic impedance between the tissues the greater the proportion of the ultrasound wave to be reflected. For example, more energy is reflected in the passage from muscle to bone than from muscle to fat. The time taken for the echoes to reach the transducer is directly proportional to the thickness of the medium and inversely proportional to the velocity of ultrasound in that particular tissue. Thus, the time delay between the transmitted pulse and its echo is a measure of the depth 
Table 11.2 Acoustic proprieties of some tissues at $1.0 \mathrm{MHz}$

\begin{tabular}{llllll}
\hline Material & $v(\mathrm{~m} / \mathrm{s})$ & $Z$ & HVL $(\mathrm{cm})$ & Interface & $R$ \\
\hline Water & 1496 & 1.49 & 4100 & Air/water & 0.999 \\
Fat & 1476 & 1.37 & 3.8 & Water/fat & 0.042 \\
Muscle & 1568 & 1.66 & 2.5 & Water/muscle & 0.054 \\
Brain & 1521 & 1.58 & 2.5 & Water/brain & 0.029 \\
Bone & 3360 & 6.20 & 0.23 & Water/bone & 0.614 \\
Air & 331 & 4.13 & 1.1 & Tissue/air & 0.999 \\
\hline
\end{tabular}

Source: adapted from Seidband (1998).

of the tissue interface (Seidband, 1998). The tissue thickness can be estimated on the basis of the time difference between the generation of the ultrasonic wave and the reception of the echoes (Thwaites, 1984).

\subsubsection{Ultrasound transducers}

Ultrasound transducers make use of the piezoelectric properties of ceramics such as barium titanate: such ceramics have the ability to generate an electric potential when mechanically strained, and conversely an electric potential can cause physical deformation of the ceramic (Peura and Webster, 1998). This ability to transform electrical energy into mechanical energy and vice versa is called the piezoelectric effect (Szabo, 2004).

The piezoelectric effect enables an ultrasound transducer to act simultaneously as a transmitter and a receiver of ultrasound energy. The transducer converts electrical signals to acoustic signals (ultrasound), which are sent to the animal's body. The tissue boundaries then produce echoes by reflecting and scattering the ultrasound waves, which turn back and are detected by the transducer, which in turn converts this acoustic signal to an electric signal (Prince and Links, 2006). Thus, with appropriate electronic circuits, the ceramic can be pulsed to transmit a short burst of ultrasonic energy as a miniature loudspeaker and then switched to act as a microphone to receive signals reflected from the interfaces of various tissue types (Seidband, 1998).

\subsubsection{Ultrasound imaging of tissues}

When ultrasonic waves are generated by a transducer and applied to the skin of an animal, the transducer receives the reflected waves and converts them into electrical power, which is then displayed on a screen in several ways, as outlined previously. Thus, ultrasound imaging systems capture the reflected energy (echoes), which is used as an indication of the position of the interface between two tissues (Goddard, 1995). The reflected sound can be used to obtain a spatial distribution of the tissues through which the ultrasonic wave has passed, and of the interfaces at which part of the ultrasonic wave was reflected. The ultrasound imaging systems process the echoes and present an image of the tissue anatomy on a display, in which each point in the image corresponds to the anatomical location of an echo-generating structure, with its brightness corresponding to the echo strength (Prince and Links, 2006). 
The spatial resolution of an image produced by ultrasound is limited by the wavelength of the ultrasound. The wavelength decreases with the increase in frequency: for example, at 2,5 and $7.5 \mathrm{MHz}$ the wavelength is approximately 0.77 , 0.31 and $0.21 \mathrm{~mm}$, respectively (Mannion, 2006). The best resolution is obtained with higher frequencies, since these are associated with a higher attenuation by biological tissues (Goddard, 1995). Thus, the choice of ultrasonic frequency should be based on two factors: (1) the desired resolution - the minimum number of elements to be differentiated - as the resolution power varies along with the ultrasound frequency; and (2) energy absorption by the medium, which increases very rapidly with the increase in ultrasound frequency, and high-frequency waves are less penetrative (Goddard, 1995; Mannion, 2006). The choice of ultrasound frequency must take into account the compromise between the type and thickness of the tissue to be analysed. For animal science, the ultrasound frequency range used is between 1 and $10 \mathrm{MHz}$ (Stouffer, 2004; Silva et al., 2006a).

\subsection{Applications of real-time ultrasound (RTU) to predict carcass composition and meat traits in large animals}

The ability of RTU to measure carcass composition and meat traits in cattle, swine, sheep and goats has been the subject of a number of studies. This section presents a comprehensive review of the methods used, degree of precision achieved and the factors affecting the use of RTU for predicting the carcass composition and meat traits of those species in vivo.

\subsubsection{Use of RTU to predict carcass composition and meat traits in cattle and swine}

Since the first reports on the use of ultrasound to predict carcass composition and meat traits in cattle (Temple et al., 1956) and swine (Claus, 1957; Dumont, 1957), it was understood that these two species would be the main target for this technology. Although cattle and swine are very different species, it has been shown that RTU can be used to assess carcass composition and meat traits in both, as will be discussed in this section.

The RTU imaging system allows the collection of anatomical measurements in live animals; these measurements, when combined with other sources of information, represent a good basis from which to estimate carcass composition (Paisley et al., 2007). During the last decade, RTU has increased in popularity and, today, has a great impact on the beef cattle and swine industry through two principal applications: as a selection tool for genetic programmes to improve the quality of the carcass and meat traits (e.g., Wilson, 1992) and as a management tool to optimize time of slaughter (Hassen et al., 1998, 1999a; DuPonte and Fergerstrom, 2006).

The use of ultrasound as a selection tool involves the collection of data relating to the carcass and meat traits of cattle (yearling bulls and heifers) and swine. This 
information is then used to select the best breeding animals in genetic improvement programmes (Wilson, 1992). Traits such as Longissimus thoracis et lumborum muscle area (LMA) and subcutaneous fat depth (SFD), usually over the 12th-13th rib, and intramuscular fat have been used as selection criteria. However, in this section, attention will be focused on the use of RTU as a management tool to improve carcass and meat quality for consumers, who are the ultimate evaluators of meat quality.

The use of RTU to measure SFD and LMA in live animals has been thoroughly documented (Perkins et al., 1992a; Greiner et al., 2003, and these two carcass traits are good estimators of lean meat yield in beef cattle (Hamlin et al., 1995; Griffin et al., 1999; Hassen et al., 1999a; May et al., 2000; Suguisawa et al., 2003) and in swine (McLaren et al., 1989; Moeller, 1990; Gresham et al., 1994; Morlein et al., 2005; Olsen et al., 2007). Similarly, ultrasound has been used to estimate intramuscular fat (marbling), which is the principal criterion determining meat quality in beef cattle and swine, and will be discussed later in this chapter. The ability to model and predict the composition of the carcass is the basis for a decision support system that allows the producers to adjust animal feeding and handling strategies according to their specific needs.

Several studies have been carried out to analyse the efficacy of ultrasound as a predictor of carcass composition prior to slaughtering in beef cattle (Perkins et al., 1992b; Smith et al., 1992; Delehant et al., 1996; Ragland et al., 1997; Griffin et al., 1999; Wall et al., 2004) and in swine (McLaren et al., 1989; Terry et al., 1989; Gresham et al., 1992, 1994; Ragland et al., 1997; Newcom et al., 2002). Optimum composition means the highest lean meat proportion, and optimum organoleptic properties. When a carcass meets these requirements, it should be sold for the highest price; if, on the other hand, the composition and organoleptic properties are not optimal, its price will be lowered. Predicting the composition of a carcass is therefore key in determining its value at the slaughter line. A low-cost and expeditious method for predicting carcass composition can be used for carcass classification at the slaughter line (Smith et al., 2008a), and for determining the price along the commercialization chain.

The methodology used to predict carcass composition should be accurate, fast and automated, and the first step in developing these prediction models is to achieve accurate measurement of the SFD and LMA, since these are the most frequently used predictors of carcass composition and quality (Perkins et al., 1992b; Delehant et al., 1996; Griffin et al., 1999; Hassen et al., 1999a; Suguisawa et al., 2003; Wall et al., 2004), and are the main price drivers for the value-based marketing system used by the meat industry. The use of RTU to measure both SFD and LMA in live animals has been well documented for both swine and beef cattle (e.g., Houghton and Turlington, 1992), and several studies have shown that it is an accurate method if the images are taken and interpreted by a trained technician (McLaren et al., 1991; Perkins et al., 1992b; Herring et al., 1994; Hassen et al., 1998). SFD is principally used to predict the lean meat content of carcasses of similar weights (Faulkner et al., 1989), while LMA is also used to predict the carcass composition (Perkins et al., 1992b; Hassen et al., 1998). The evaluation of the accuracy of ultrasound measurements of SFD and LMA is the first step in assessing the applicability of the technology (Robinson et al., 1992) for this purpose. Several articles have 
focused on the accuracy of the measurement of these carcass traits in beef cattle and in swine. Table 11.3 summarizes the values of correlation coefficients $(r)$ and confidence interval (CI) between SFD and LMA measured by ultrasound and the homologous measurements taken on the carcass for beef cattle and swine.

In cattle, the correlation coefficients between SFD and LMA measured by ultrasound and the homologous measurements taken on the carcass range from 0.70

Table 11.3 Correlation coefficients $(r)$ and confidence interval (CI) between SFD and LMA measured by ultrasound and the homologous measurements taken on the carcass attained by several authors for cattle and swine

\begin{tabular}{|c|c|c|c|c|c|}
\hline \multirow[t]{2}{*}{ Species } & \multirow[t]{2}{*}{ Reference } & \multicolumn{2}{|c|}{ SFD } & \multicolumn{2}{|c|}{ LMA } \\
\hline & & $r$ & CI $(95 \%)$ & $r$ & CI $(95 \%)$ \\
\hline \multirow[t]{13}{*}{ Cattle } & $\begin{array}{l}\text { Hedrick et al. } \\
\quad(1962)\end{array}$ & 0.71 & $0.56-0.81$ & 0.88 & $0.81-0.92$ \\
\hline & Davis et al. (1964) & 0.90 & $0.84-0.93$ & 0.87 & $0.79-0.82$ \\
\hline & $\begin{array}{l}\text { Henderson-Perry } \\
\text { et al. (1989) }\end{array}$ & 0.86 & $0.82-0.89$ & 0.76 & $0.69-0.81$ \\
\hline & Brethour (1992) & 0.90 & $0.88-0.91$ & 0.58 & $0.48-0.66$ \\
\hline & $\begin{array}{l}\text { Perkins et al. } \\
\quad(1992 \mathrm{a})\end{array}$ & 0.75 & $0.71-0.78$ & 0.60 & $0.54-0.65$ \\
\hline & $\begin{array}{l}\text { Robinson et al. } \\
\quad(1992)\end{array}$ & 0.91 & $0.74-0.93$ & 0.88 & $0.76-0.94$ \\
\hline & Smith et al. (1992) & 0.82 & $0.75-0.87$ & 0.63 & $0.52-0.72$ \\
\hline & $\begin{array}{l}\text { Hassen et al. } \\
\quad(1998)\end{array}$ & 0.70 & $0.61-0.77$ & 0.48 & $0.35-0.59$ \\
\hline & $\begin{array}{l}\text { Griffin et al. } \\
\quad(1999)\end{array}$ & - & - & 0.52 & $0.10-0.78$ \\
\hline & May et al. (2000) & 0.81 & $0.76-0.85$ & 0.61 & $0.52-0.69$ \\
\hline & Silva et al. (2004) & 0.86 & $0.76-0.92$ & - & - \\
\hline & Fixed effect model & 0.84 & $0.78-0.88$ & 0.66 & $0.63-0.68$ \\
\hline & $\begin{array}{l}\text { Random effects } \\
\text { model }\end{array}$ & 0.84 & $0.78-0.88$ & 0.72 & $0.62-0.80$ \\
\hline \multirow[t]{8}{*}{ Swine } & Busk (1986) & 0.90 & $0.86-0.93$ & - & - \\
\hline & $\begin{array}{l}\text { McLaren et al. } \\
\text { (1989) }\end{array}$ & 0.55 & $0.40-0.67$ & 0.61 & $0.48-0.72$ \\
\hline & $\begin{array}{l}\text { McLaren et al. } \\
\text { (1991) }\end{array}$ & 0.86 & $0.74-0.93$ & 0.80 & $0.63-0.89$ \\
\hline & $\begin{array}{l}\text { Gresham et al. } \\
\text { (1992) }\end{array}$ & 0.49 & $0.34-0.62$ & - & - \\
\hline & $\begin{array}{l}\text { Ragland et al. } \\
\text { (1997) }\end{array}$ & 0.84 & $0.81-0.87$ & 0.74 & $0.69-0.78$ \\
\hline & $\begin{array}{l}\text { Moeller and } \\
\text { Christian } \\
\text { (1998) }\end{array}$ & 0.87 & $0.85-0.88$ & 0.74 & $0.71-0.77$ \\
\hline & Fixed effect model & 0.85 & $0.84-0.86$ & 0.72 & $0.70-0.74$ \\
\hline & $\begin{array}{l}\text { Random effects } \\
\text { model }\end{array}$ & 0.82 & $0.74-0.88$ & 0.70 & $0.64-0.75$ \\
\hline
\end{tabular}


to 0.91 and from 0.48 to 0.88 , respectively. For swine, the correlation between ultrasound and the homologous carcass measurements are very similar $(0.49-0.90$ and $0.61-0.80$ for SFD and LMA, respectively).

Although these correlations are generally significant, the data presented in Table 11.3 shows some variation in the correlation coefficients between different studies and species. This variation is influenced by several factors, namely the ultrasound equipment used, differences between animal and carcass position after slaughter, methods for RTU image analysis and operator training (Robinson et al., 1992; Herring et al., 1994; Stouffer, 2004). All these factors contribute to reducing the accuracy of the RTU technique (Houghton and Turlington, 1992). However, in recent years, important advances have been made in ultrasound technology, which allow for increasing accuracy and reliability in measuring the SFD and LMA (Lusk et al., 2003). Moreover, efforts have been made to improve image acquisition protocols by certified independent technicians (Stouffer, 2004). Additionally, the captured RTU images can be sent to a central laboratory and analysed by trained staff (Greiner et al., 2003). Similar procedures could be adopted to optimize the use of the RTU technique in swine (Moeller, 2002; Schwab et al., 2010).

\subsubsection{Use of RTU to predict carcass composition and meat traits in sheep and goats}

One of the first ultrasound scanning examinations to predict the composition of sheep carcasses was reported in the late 1950s (Campbell et al., 1959). Since then, numerous studies have been carried out with the aim of predicting carcass composition and meat traits in small ruminants (Table 11.4). The application of RTU technology to small ruminants has been centred on the development of genetic improvement programmes for fat reduction and on the prediction of carcass composition (e.g., Simm, 1987; McEwan et al., 1989), which also proved useful in marketing decisions (Alliston, 1980; Leeds et al., 2007). Particularly in sheep, an excess of fat in the carcass is a major problem that reduces the commercial value of the animal (Sañudo et al., 2000). To overcome this problem, the use of RTU technology has been shown to be very effective in the evaluation of carcass fat levels (Simm et al., 2002; MacFarlane and Simm, 2008). In addition, for sheep and goats, RTU shows great potential for in vivo evaluation of carcass composition and meat traits. In recent years, several works have been published that clearly show that the RTU technique allows good estimates of the composition of the carcass to be obtained. These studies aimed to predict carcass composition in adult animals (Hopkins et al., 2007; Teixeira et al., 2008), market lambs (Teixeira et al., 2006; Leeds et al., 2008; Orman et al., 2008; Thériault et al., 2009; Emenheiser et al., 2010; Orman et al., 2010) or light carcasses (Ripoll et al., 2009). Although the results obtained were generally good, attention must be paid to the factors that lead to inaccuracy in the RTU technique when used for small ruminants. These factors include wool or hair, identification of measurement points, fat level and image interpretation and analysis. 
Table 11.4 Summary of studies conducted with sheep and goat for predicting in vivo carcass traits using the RTU technique

\begin{tabular}{|c|c|c|c|}
\hline Species & Reference & Equipment & Objective \\
\hline \multirow[t]{21}{*}{ Sheep } & Kempster et al. (1982) & Danscanner & Predicting carcass composition \\
\hline & McEwan et al. (1989) & $\begin{array}{l}\text { Aloka; } 3 \mathrm{MHz} \text { and Toshiba SAL 22; } \\
5 \mathrm{MHz}\end{array}$ & $\begin{array}{l}\text { Accuracy of RTU measurements and predicting carcass } \\
\text { composition }\end{array}$ \\
\hline & Ramsey et al. (1991) & Toshiba SAL 32B; $5 \mathrm{MHz}$ & Predicting carcass composition \\
\hline & Young et al. (1992) & Aloka SSD-210 DXII; $5 \mathrm{MHz}$ & Predicting carcass composition \\
\hline & Delfa et al. (1995a) & Toshiba SAL 32B; $5 \mathrm{MHz}$ & $\begin{array}{l}\text { Accuracy of RTU measurements and predicting carcass } \\
\text { composition }\end{array}$ \\
\hline & Stanford et al. (1995a) & Aloka SSD 500V; $2 \mathrm{MHz}$ & $\begin{array}{l}\text { Accuracy of RTU measurements and predicting carcass } \\
\text { composition }\end{array}$ \\
\hline & Glasbey et al. (1996) & Vetscan MKI; 5 MHz & Accuracy of RTU measurements \\
\hline & Hopkins et al. (1996) & Aloka $500 \mathrm{~V} ; 3.5 \mathrm{MHz}$ & $\begin{array}{l}\text { Accuracy of RTU measurements and predicting carcass } \\
\text { composition }\end{array}$ \\
\hline & Fernández et al. (1997) & Toshiba SAL 32B; $5 \mathrm{MHz}$ & Accuracy of RTU measurements \\
\hline & Silva et al. (2005) & Aloka 500V; $7.5 \mathrm{MHz}$ & Predicting body and carcass chemical composition \\
\hline & Silva et al. (2006a) & Aloka $500 \mathrm{~V} ; 5$ and $7.5 \mathrm{MHz}$ & Predicting carcass composition \\
\hline & Teixeira et al. (2006) & Aloka $500 \mathrm{~V} ; 5$ and $7.5 \mathrm{MHz}$ & Predicting carcass composition \\
\hline & Hopkins et al. (2007) & Honda HS-1201; $5 \mathrm{MHz}$ & $\begin{array}{l}\text { Accuracy of RTU measurements and predicting carcass } \\
\text { composition }\end{array}$ \\
\hline & Silva et al. (2007a) & Aloka 500V; $7.5 \mathrm{MHz}$ & Predicting carcass composition \\
\hline & Leeds et al. (2008) & Aloka 500V; $3.5 \mathrm{MHz}$ & Accuracy of RTU measurements and predicting yields \\
\hline & Orman et al. (2008) & Dynamic imaging, $7.5 \mathrm{MHz}$ & Accuracy of RTU measurements \\
\hline & Ripoll et al. (2009) & Aloka SSD 900; $7.5 \mathrm{MHz}$ & $\begin{array}{l}\text { Accuracy of RTU measurements and predicting carcass } \\
\text { composition }\end{array}$ \\
\hline & Thériault et al. (2009) & Ultrascan $50 ; 3.5 \mathrm{MHz}$ & Accuracy of RTU measurements \\
\hline & Emenheiser et al. (2010) & Aloka 500V; $3.5 \mathrm{MHz}$ & Accuracy of RTU measurements \\
\hline & Orman et al. (2010) & Dynamic Imaging, $7.5 \mathrm{MHz}$ & Accuracy of RTU measurements \\
\hline & Ripoll et al. (2010) & Aloka SSD 900; $7.5 \mathrm{MHz}$ & $\begin{array}{l}\text { Accuracy of RTU measurements and predicting carcass } \\
\text { composition }\end{array}$ \\
\hline
\end{tabular}


Table 11.4 Continued

\begin{tabular}{|c|c|c|c|}
\hline Species & Reference & Equipment & Objective \\
\hline \multirow[t]{6}{*}{ Goat } & Delfa et al. (1995b) & Toshiba SAL 32B/5 MHz & $\begin{array}{l}\text { Accuracy of RTU measurements and predicting carcass } \\
\text { composition }\end{array}$ \\
\hline & Stanford et al. (1995b) & Keikei CS-3000/3.5 MHz & Accuracy of RTU measurements \\
\hline & Delfa et al. (1996) & Toshiba SAL 32B/5 MHz & $\begin{array}{l}\text { Accuracy of RTU measurements and predicting carcass } \\
\text { composition }\end{array}$ \\
\hline & Mesta et al. (2004) & Aloka 500, $5 \mathrm{MHz}$ & Accuracy of RTU measurements \\
\hline & Teixeira et al. (2008) & Toshiba SAL 32B/5 MHz & $\begin{array}{l}\text { Accuracy of RTU measurements and predicting carcass } \\
\text { composition }\end{array}$ \\
\hline & Monteiro (2010) & Aloka $500,5 \mathrm{MHz}$ & $\begin{array}{l}\text { Accuracy of RTU measurements and predicting carcass } \\
\text { composition }\end{array}$ \\
\hline
\end{tabular}


The value of clipping or shearing the wool or hair at the measuring points of sheep and goats is a controversial issue. One perspective is that the procedure is useful, as it helps to avoid aberrant echoes caused by air bubbles trapped between the conductive medium and wool or hair (Kempster et al., 1982; Stouffer, 1991, Silva et al., 2006a; Leeds et al., 2008). Air bubbles are the cause of low quality images because the ultrasonic beams can dissipate quickly in the air. The necessity of shearing animals was verified by McLaren et al. (1991): after studying data from seven sheep that had not been shorn, an increase from $0.15(P>0.05)$ to $0.59(P<0.01)$ was observed for the correlation between fat thickness measured with ultrasound and fat thickness measured in carcass. The main argument against shearing is the need for the whole ultrasound examination process to be carried out quickly (Hopkins et al., 1996; Teixeira et al., 2008). This issue can be of great economic importance when RTU examinations are performed in a large number of animals, as is the case in commercial herds. Poor acoustic contact between the probe and skin may cause RTU measurements to be underestimated, and it is therefore necessary to increase the pressure on the probe, which causes a deformation of superficial tissues (McEwan et al., 1989; McLaren et al., 1991). To overcome this problem, Ramsey et al. (1991) and Young and Deaker (1994) pointed out the possibility of following the tissue deformation through the image on the monitor, allowing it to be immediately corrected. Using a greater amount of conductive medium and the use of a standoff pad between probe and skin are other procedures that can reduce the tissue deformation problem.

In most studies involving sheep and goats, ultrasonic measurements are carried out along the midline of the thoracic and lumbar regions, usually between the 12th thoracic vertebra and 4th lumbar vertebra, using the Longissimus thoracis et lumborum (LTL) muscle and thoracic and lumbar vertebrae for orientation. Subcutaneous fat depth above the LTL muscle and muscle depth and area are the parameters usually measured in RTU examinations. A large number of studies (McEwan et al., 1989; Silva et al., 2006a; Teixeira et al., 2006; Hopkins et al., 2007; Silva et al., 2007a; Leeds et al., 2008; Teixeira et al., 2008; Thériault et al., 2009; Emenheiser et al., 2010; Orman et al., 2010) have found a significant correlation $(r>0.6 ; P<0.01)$ between both fat and muscle RTU measurements and the corresponding carcass measurements in those regions. The placement of the probe at reference points must be correct, since SFD and LTL muscles vary significantly over short distances either cranio-caudally (Delfa et al., 1991; Silva et al., 2007a) or medium-laterally (Simm, 1983; Korn et al., 2005). In addition, anatomical distortions arising from the position of the animals and skin flexibility may also contribute to discrepancies between RTU and carcass measurements (Thwaites, 1984; Leeds et al., 2008). This problem is more evident in young animals, in which the skin is more flexible and the thickness of tissues is lower (Thwaites, 1984; Silva et al., 2006a; Ripoll et al., 2009).

Ultrasound measurements of other regions are also carried out, including over the sternum (Delfa et al., 1996, 2000; Silva et al., 2005; Teixeira et al., 2008) and grade rule (GR) measurement, which is taken between the 11th and 12th ribs at a lateral distance of $11 \mathrm{~cm}$ from the spine (Hopkins et al., 1993; Thériault et al., 
2009). The sternum region is particularly appropriate for the assessment of fat thickness in goats (Delfa et al., 1996, 2000). In fact, in this species the subcutaneous fat layer in the thoracic and lumbar regions is usually very thin, and is therefore more difficult to measure (Teixeira, 2009).

It has been observed that the accuracy of subcutaneous fat thickness measurements is higher in fatter animals within the same species and between different species (McLaren et al., 1991; Stouffer, 2004; Silva et al., 2006a). In general, RTU measurements obtained in lambs (Young and Deaker, 1994; Silva et al., 2006a; Ripoll et al., 2010) or in kids (Stanford et al., 1995b; Monteiro, 2010) lead to difficulties in SF measurement due to the lower thickness of this tissue. One way to overcome the problem of thin subcutaneous fat is the use of higher-frequency probes, as demonstrated by Silva et al. (2006a) and Teixeira et al. (2006), who showed that a frequency of $7.5 \mathrm{MHz}$ outperformed $5 \mathrm{MHz}$ in measuring SFD. The 7.5 MHz probe showed higher resolution and lower penetration (Silva et al., 2006a). Generally, the first $6 \mathrm{~mm}$ are the focus of attention, comprising skin and subcutaneous fat (Gooden et al., 1980). Therefore, the interface between skin and subcutaneous fat should be located with precision, because the fat is only a few millimetres thick (Gooden et al., 1980; McEwan et al., 1989). The difficulty of determining the interface between skin and subcutaneous fat led some authors to include the skin in the measurement of SFD (Kempster et al., 1982; Silva et al., 2005; Thériault et al., 2009).

Accurate depth measurements require clear identification of the tissues and their interfaces. RTU equipment usually contains an internal measurement system that typically has a resolution of $1 \mathrm{~mm}$ (McEwan et al., 1989; Fernández et al., 1997). This resolution, as discussed previously, undermines the accuracy of SF measurements when lean animals are examined (Fernández et al., 1997; Silva et al., 2006a) or when it is necessary to monitor variations of tissue thickness in growing animals (Hamby et al., 1986; Silva et al., 2005). This resolution issue was reported by Young et al. (1992) who took fat and muscle thickness measurements in a group of sheep using an RTU associated with a video system for image recording and an image analysis programme. Young et al. (1992) observed superior measurement repeatability with their approach, including image recording and analysis, compared with measurements performed directly on the equipment monitor. The difference in repeatability of the two approaches was connected to the resolution, which was $0.1 \mathrm{~mm}$ on the image analysis system and $1 \mathrm{~mm}$ on the monitor. Similar results were also observed by Silva et al. (2005) in a study with growing lambs. They report that better results were obtained when a high-frequency probe $(7.5 \mathrm{MHz})$ was used, allowing an image resolution of $0.2 \mathrm{~mm}$, which was capable of detecting differences in SFD between animals. This is undoubtedly a strong justification for recording ultrasonic images for later analysis. Other factors that justify the recording of images and their subsequent analysis are the shorter time required to evaluate the animals (Glasbey et al., 1996; Silva et al., 2006a); the possibility of obtaining several measurements from the same image including irregular areas (Silva et al., 2007a); and improvements in repeatability, since the interpretation of the images is more important than its acquisition (McLaren et al., 1991). 
Problems in identifying tissue interfaces may also arise in fat animals. Indeed, in fat lambs, two or even three layers of subcutaneous fat can be formed, which can be problematic for the interpretation of images taken at the interface between skin and subcutaneous fat (Miles et al., 1972; Silva et al., 2005; Thériault et al., 2009) and can lead to an underestimation of SFD. This underestimation can have serious implications when the RTU measurements aim to select animals with lean carcasses (Gibson and Alliston, 1983; Brethour, 1992).

Over the years, several reports have shown that RTU is a suitable technique for predicting carcass composition both in sheep (Kempster et al., 1982; McEwan et al., 1989; Ramsey et al., 1991; Young and Deaker, 1994; Silva et al., 2005, 2006a; Teixeira et al., 2006; Hopkins et al., 2007; Ripoll et al., 2009) and goats (Delfa et al., 1995a, 1996; Teixeira et al., 2008). In general, these studies develop models which are able to explain the variation in carcass composition in terms of muscle, fat and bone content. Very often, the best models include RTU measurements and body weight. For example, Silva et al. (2006a) and Ripoll et al. (2009) used models for lambs that included the body weight and one or two RTU measurements, which demonstrate $59-99 \%$ and $51-98 \%$ of the variation in muscle and fat content, respectively. For goats, Teixeira et al. (2008) also observed the value of body weight in combination with RTU measurements to predict carcass muscle content $\left(r^{2}=0.90 ; P<0.01\right)$, carcass fat $\left(r^{2}=0.92 ; P<0.01\right)$ and total body fat $\left(r^{2}=0.92 ; P<0.01\right)$.

\subsection{Applications of RTU to predict carcass composition and meat traits in small animals and fish}

This section presents an overview of the research conducted with RTU to measure carcass composition and meat traits in poultry, rabbits and fish.

\subsubsection{Use of RTU to predict carcass composition and meat traits in poultry}

Intensive research into the quality of poultry meat began after World War II, mainly in industrialized countries (Grashorn, 2010). Since then, the successful application of science (health, management, nutrition and genetics) to business in a challenging industry has led to astounding changes in the final product (Boyle, 2006). In the $1950 \mathrm{~s}$, to grow a $1.8 \mathrm{~kg}$ broiler, it took 90 days (20 g body weight gain day ${ }^{-1}$ ), with a consumption of $3.6 \mathrm{~kg}$ of feed $\mathrm{kg}^{-1}$ of body weight gain, producing about a breast meat yield of approximately $12 \%$. Today, to grow a broiler with the same body weight takes less than 39 days ( 46 g body weight gain day ${ }^{-1}$ ), with less than half the feed used previously $\left(1.7 \mathrm{~kg}\right.$ of feed $\mathrm{kg}^{-1}$ of body weight gain) and with a breast meat yield of 19\% (Arthur and Albers, 2003; Boyle, 2006). These changes have mostly been implemented through selection methods that efficiently improved the yield of the carcass, particularly the breast and leg muscles (Berri et al., 2005; Duclos et al., 2006). As stated in several papers, the breast 
is the most valuable part of a poultry carcass (Silva et al., 2006b; Larivière et al., 2009) and the breast muscle thickness is a good indicator of poultry carcass composition (Michalik et al., 1999, Rymkiewicz and Bochno, 1999). Poultry carcass traits have therefore been measured with both invasive (slaughtering and dissection of progenies/sibs) or in vivo non-invasive methods (Zerehdaran et al., 2005; Larivière et al., 2009). The latter are particularly relevant when serial determinations of carcass traits in the same animal are required. For poultry, as for other species, numerous studies have described non-invasive methods for the evaluation of carcass composition and meat and fat traits. For example, methods, such as TOBEC (Latshaw and Bishop, 2001), DXA (Mitchell et al., 1997; Swennen et al., 2004), MRI (Mitchell et al., 1991; Kallweit et al., 1994; Kövér et al., 1998a; Scollan et al., 1998; Davenel et al., 2000) or CT (Bentsen and Sehested, 1989; Svihus and Katle, 1993; Andrassy-Baka et al., 2003) have been shown to be useful for poultry research. Among these techniques, MRI and CT have been identified as being particularly accurate. However, the high cost of the equipment required for these techniques, combined with the fact that the equipment is not portable, severely limits their routine application in poultry research. Real-time ultrasonography has been used for several years in poultry science studies to predict carcass composition and meat traits (Bochno et al., 2000; Melo et al., 2003; Silva et al., 2006b; Larivière et al., 2009). Ultrasound studies on broiler chickens to predict carcass traits were focused mainly on abdominal fat (e.g., Melo et al., 2003; Arceo et al., 2009) and breast measurements (e.g., Silva et al., 2006b; Kleczek et al., 2009). The results obtained using RTU to predict poultry carcass traits are given in Table 11.5.

In general, the results show that RTU measurements are useful for developing models of broiler breast and leg cuts and lean tissue. It has also been observed in several studies that the best models combine body weight (BW) with RTU measurements (Konig et al., 1998; Melo et al., 2003; Silva et al., 2006b; OviedoRondón et al., 2007). The use of BW in combination with RTU measurements in models for predicting carcass composition is a common practice since BW is closely related to key carcass traits and there are minimal costs associated with its measurement. Using BW combined with RTU measurements for chicken breast, it was possible to account for between $85 \%$ and $97 \%$ of the observed variation in breast yield and between $63 \%$ and $99 \%$ of the observed variation in total lean meat content. Based on these results, it is understandable that some reports recommend the use of this non-invasive technique as a valuable tool for selection schemes in broiler breeding (Zerehdaran et al., 2005; Oviedo-Rondón et al., 2007). Ultrasound is also recognized as being sufficiently accurate to monitor the changes in breast yield that occur over the course of a bird's growth; it will therefore prove to be a powerful tool for making the necessary adjustments in feeding regimes to enhance productivity (Dixson and Teeter, 2001; Oviedo-Rondón et al., 2007) and in deciding the optimal weight for slaughter (Oviedo-Rondón et al., 2007). Nevertheless, ongoing study of the use of RTU in poultry research is necessary in order to optimize methods and equipment. Several RTU variables such as breast thickness (e.g., Dixson and Teeter, 2001), breast area obtained both 
Table 11.5 Summary of trials with broilers for prediction of carcass traits from breast measurements obtained by RTU alone or associated with body weight (BW)

\begin{tabular}{|c|c|c|c|c|c|c|}
\hline Reference & Equipment & Probe & $n$ & Dependent variable & Independent variables & $r^{2}$ \\
\hline \multirow[t]{2}{*}{ Konig et al. (1998) } & Aloka $500 \mathrm{~V}$ & $5 \mathrm{MHz}$, linear & 150 male & Breast yield, \% & 2 Breast area measurements & 0.54 \\
\hline & & & 108 female & Breast yield, \% & 2 Breast area measurements & 0.50 \\
\hline \multirow[t]{2}{*}{ Michalik et al. (1999) } & & & 77 male & Total lean, $\mathrm{g}$ & BW + Breast thickness & 0.64 \\
\hline & & & 76 female & Total lean, $\mathrm{g}$ & $\mathrm{BW}+$ Breast thickness & 0.59 \\
\hline \multirow[t]{4}{*}{ Rémignon et al. (2000) } & Toshiba SAL38B & $5 \mathrm{MHz}$, linear & 48 & Breast, $\mathrm{g}$ & $\begin{array}{l}\mathrm{BW}+\text { Breast cross-sectional } \\
\text { area }\end{array}$ & 0.89 \\
\hline & & & & Breast yield, \% & $\begin{array}{l}\mathrm{BW}+\text { Breast cross-sectional } \\
\text { area }\end{array}$ & 0.63 \\
\hline & & & 104 & Breast, $g$ & $\begin{array}{l}\mathrm{BW}+\text { Breast cross-sectional } \\
\text { area }\end{array}$ & 0.80 \\
\hline & & & & Breast yield, \% & $\begin{array}{l}\text { BW+ Breast cross-sectional } \\
\text { area }\end{array}$ & 0.60 \\
\hline \multirow[t]{2}{*}{ Dixson and Teeter (2001) } & & & & Breast, $\mathrm{g}$ & Breast thickness & 0.90 \\
\hline & & & & Total lean, $g$ & Breast thickness & 0.90 \\
\hline Melo et al. (2003) & Ekhoson $500 \mathrm{~V}$ & $7.5 \mathrm{MHz}$, linear & 96 & Breast, $g$ & BW + Breast thickness & 0.85 \\
\hline \multirow[t]{2}{*}{ Silva et al. (2006b) } & Aloka $500 \mathrm{~V}$ & 7.5 MHz, linear & 103 & Breast yield, \% & $\mathrm{BW}+$ Breast volume & 0.52 \\
\hline & & & & Breast, g & $\mathrm{BW}+$ Breast volume & 0.92 \\
\hline \multirow{3}{*}{$\begin{array}{l}\text { Oviedo-Rondón et al. } \\
\text { (2007) }\end{array}$} & Aloka $500 \mathrm{~V}$ & 3.5 MHz, linear & & Breast, g & $\mathrm{BW}+$ Breast area & 0.97 \\
\hline & & & & Legs, g & BW + Breast area & 0.98 \\
\hline & & & & Total meat, $\mathrm{g}$ & $\mathrm{BW}+$ Breast area & 0.99 \\
\hline
\end{tabular}


Table 11.5 Continued

\begin{tabular}{|c|c|c|c|c|c|c|}
\hline Reference & Equipment & Probe & $n$ & Dependent variable & Independent variables & $r^{2}$ \\
\hline \multirow[t]{2}{*}{ Kleczek et al. (2009) } & Dramiński Animal & $7 \mathrm{MHz}$, sector & 40 male & Breast, $\mathrm{g}$ & Breast thickness & 0.22 \\
\hline & & & 40 female & Breast, $\mathrm{g}$ & Breast thickness & 0.45 \\
\hline Larivière et al. (2009) & Pie Medical 100 & $5 \mathrm{MHz}$, linear & 24 & Breast, $\mathrm{g}$ & Breast thickness & 0.62 \\
\hline
\end{tabular}


by perpendicular (e.g., Silva et al., 2006b) or longitudinal scanning (e.g., OviedoRondón et al., 2007), or breast volume (e.g., Silva et al., 2006b) have been used as independent variables in linear regression equations for in vivo estimation of the total breast muscle content. The fact that these variables are of different origins underlines the need for the selection of one site and a specific scanning procedure. There are also concerns related to the choice of equipment: some studies use a linear probe whereas others use a sector probe. The images resulting from breast scanning with a sector probe (Fig. 11.2a) are very different from those obtained with a linear probe (Fig. 11.2b). This difference causes additional difficulties in the interpretation of tissue interfaces. The frequency and length of the probe are also sources of inaccuracy. Using a $3.5 \mathrm{MHz}$ with $17.5 \mathrm{~cm}$ length probe, as is usually employed in large animals, allows a wider ultrasonic window to be examined, which in turn allows better identification of the anatomical site and hence a consistent measurement of the muscle area (Oviedo-Rondón et al., 2007). If small probes are used, the anatomical site must be correctly identified before ultrasound image acquisition can be carried out (Konig et al., 1997; Silva et al., 2006b). On the other hand, the high probe frequency reported by Silva et al. (2006b) is potentially more useful in monitoring small changes in breast muscle thickness, particularly in smaller birds, because, as a result of a direct relationship between frequency and attenuation, a lower-frequency probe is more appropriate for deep tissue examinations, whereas a high-frequency probe is better suited to the examination of superficial structures (Goddard, 1995; Silva et al., 2006b).

From a practical point of view, the time needed to acquire a RTU image is very important (Silva et al., 2006b; Oviedo-Rondón et al., 2007). The correct placement of the probe at the anatomical site, along with proper acoustic contact between the probe and bird are crucial for image quality (Konig et al., 1997, 1998; Silva et al., 2006b; Oviedo-Rondón et al., 2007). In the studies just listed, 50-76 birds were examined per hour, and the RTU images were captured with minimum stress, as only manual restraint was necessary, with no detached feathers. Additional time is necessary for image analysis. Two different procedures can be followed: the first takes advantage of the equipment callipers and software, with

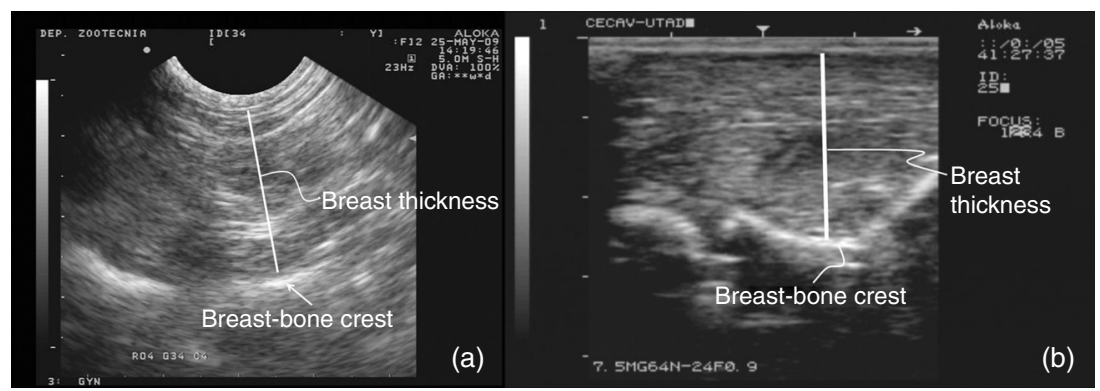

Fig. 11.2 RTU images obtained from cross-sectional view of broiler chicken breast muscle: (a) with a $7.5 \mathrm{MHz}$ sector probe and (b) with a $7.5 \mathrm{MHz}$ linear probe. Breast bone crest and breast thickness were represented. 
measurements taken during the image capturing session (Kleczek et al., 2009); in the second, images are stored for subsequent image analysis (Konig et al., 1997; Rémignon et al., 2000; Silva et al., 2006b; Oviedo-Rondón et al., 2007; Larivière et al., 2009). In the latter process, a higher-resolution power is expected, with the result that the measurements obtained are more accurate (Young et al., 1992).

\subsubsection{Use of RTU to predict carcass composition and meat traits in rabbit}

Rabbit meat is an important product in the Mediterranean areas of Europe, and is also popular in other parts of the world (FAOSTAT, 2010). In recent years, several studies have focused on rabbit meat and carcass traits (Hernández et al., 2004; Larzul et al., 2005). A relationship has been established between growth rate on the one hand, and carcass characteristics and meat quality on the other (Gondret et al., 2005; Pascual and Pla, 2007). Moreover, rabbit is a good experimental model for meat carcass traits because experiments on rabbits can be performed more quickly and at a lower cost than those on other species (Hernández et al., 2006). To further current understanding of rabbit carcass and meat traits, several studies have called for techniques that can evaluate these features in vivo (Szabo et al., 1999). Although several non-invasive techniques have been successfully used to evaluate carcass composition in rabbits, such as CT (Szendrö et al., 1992, 2008; Romvári et al., 1996), MRI (Kövér et al., 1998b) and TOBEC (Fortun-Lamothe et al., 2002), only a few studies have been conducted using RTU. Some of these studies are related to the prediction of fat deposits (Pascual et al., 2000, 2002, 2004; Dal Bosco et al., 2003; Castellini et al., 2006; Quevedo et al., 2006) while others are related with carcass and meat traits (Silva et al., 2007b, 2008a, 2008b, 2009). In the pioneering study by Pascual et al. (2000), it was shown that RTU was suitable for fat deposit evaluation. A method based on the measurement of perirenal fat thickness at a fixed anatomical location (8th-9th thoracic vertebrae) was developed and accurate results for predicting carcass perirenal fat weight $\left(r^{2}=0.95 ; n=42\right)$ and total fat weight $\left(r^{2}=0.93 ; n=42\right)$ were obtained.

In rabbits, the ability to assess the fat content of the carcass is of little value because this species has only a small dissectible fat content (Pascual and Pla, 2007). For rabbit carcasses, the evaluation was mainly focused on meat percentage and muscularity, defined as the ratio between meat and bone (Lukefahr and Ozimba, 1991). Several reports have shown that muscularity or cutability attributes may be improved through selection programmes (Lukefahr et al., 1982, 1983). Thus, the development of in vivo measurements of muscularity and carcass composition in rabbits using RTU has potentially useful applications in genetic improvement programmes or simply in economic carcass evaluation (Silva et al., 2009). In rabbits, good results were achieved in studies using live body measurements to predict the muscle percentage and muscularity in the carcass (Lukefahr et al., 1982; Lukefahr and Ozimba, 1991; Michalik et al., 2006). Lukefahr and Ozimba (1991); it was found that the lean cut weight (measure of cutability) of the loin was accurately predicted using body weight and loin width $\left(r^{2}=0.797\right)$. 
Several recent studies have assessed the suitability of in vivo RTU measurements for assessing rabbit carcass composition and muscularity of loin and leg (Silva et al., 2007b, 2008a, 2008b, 2009). The results reported by these studies clearly showed that measurements obtained from RTU images could account for a large amount of the variation observed in carcass composition and muscularity traits. By employing a $7.5 \mathrm{MHz}$ probe and carrying out image analysis using Image J software for RTU images, 51-94\% of the variation in carcass chemical composition (Silva et al., 2007b) and $49-77 \%$ of the variation in carcass meat and bone weight (Silva et al., 2009) could be explained with LTL muscle measurements (Fig. 11.3). These results are close to those obtained with CT (Szendrö et al., 1992). Silva et al. (2007b, 2009) pointed out that with this system it was possible to estimate the amount of loin muscle $(r=0.80 ; P<0.01)$.

Moreover, after RTU image analysis, it was possible to predict the LTL muscle volume of the carcass from the in vivo LTL volume $\left(r^{2}=0.81\right)$, which can be calculated from area measurements obtained with multiple scanning images and by using Cavalieri's principle (Silva et al., 2008a). As stated previously, muscularity is an important trait in rabbit carcasses and in vivo RTU is able to accurately estimate loin muscularity ( $r$ between 0.76 and $0.81 ; P<0.01$ ) (Silva et al., 2009). However, for leg muscularity, lower coefficients of correlation ( $r$ from $0.15 ; P>$ $0.05-0.46 ; P<0.01$ ) were found (Silva et al., 2008b). These results highlighted the need to improve the procedures related to RTU and carcass measurements so that increased accuracy can be achieved when using RTU to determine hind leg

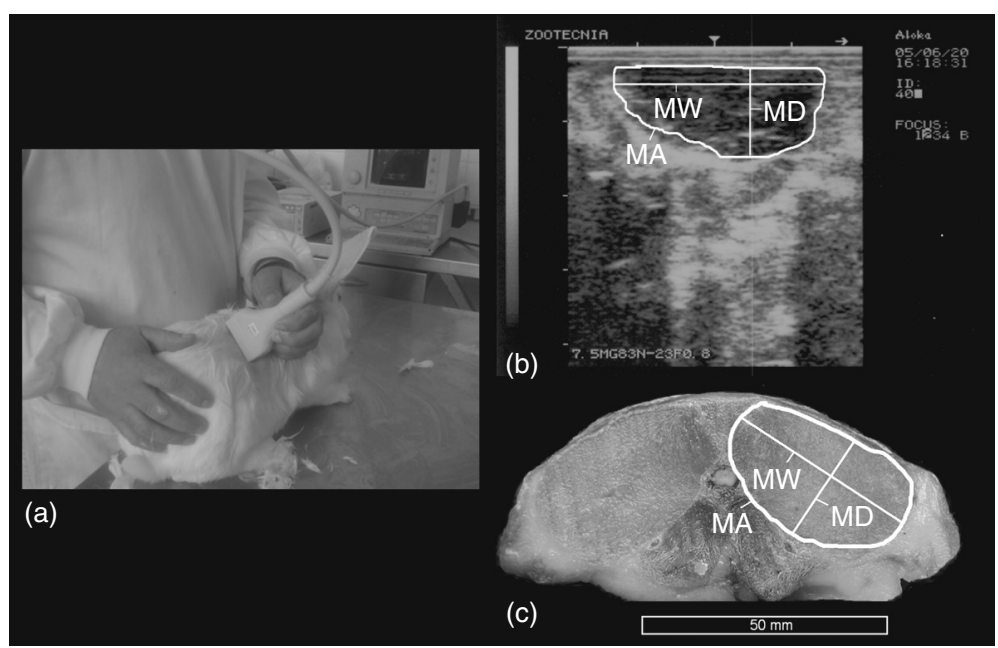

Fig. 11.3 (a) RTU image acquisition procedure with a linear probe placed over loin region between the 6th and 7th lumbar vertebrae. Note the hair clipped close to the skin. (b) RTU image taken in vivo showing the representations of longissimus thoracis et lumborum muscle area (MA), width (MW) and depth (MD) measurements. (c) Carcass cut section at homologous anatomical position showing the representations of equivalent longissimus thoracis et lumborum muscle measurements. 
muscularity. Nevertheless, the results obtained from these studies are encouraging as far as the use of in vivo RTU to predict rabbit carcass traits is concerned; further research is necessary to improve the practicability of RTU and image analysis for extensive use in the evaluation of rabbit carcasses, since other attributes such as animal restraint, equipment mobility, ease of use and non-invasive nature have already been well established for this technique. The need for the removal of hair from the ultrasound measurement site is also inconvenient, and this problem will need to be addressed in order to improve the practicability of the technique in rabbits.

\subsubsection{Use of RTU to predict carcass composition and meat traits in fish}

An understanding of the carcass composition, and particularly the fat content, of live fish is important for feeding, breeding and genetics, and for increasing the meat yield of the carcass. It is also an important factor in consumer acceptance (Probert and Shannon, 2000; Romvári et al., 2002; Veliyulin et al., 2005). Traditionally, carcass composition in fish was determined by comparative slaughtering followed by chemical analysis (Oberle et al., 1997). Other methods such as ultrasound velocity (Suvanich et al., 1998; Sigfusson et al., 2000) or near-infrared techniques (Wold and Isaksson, 1997) are based on fillet samples or dead fish. However, fish production is heavily dependent on quick, accurate and, above all, non-invasive methods to predict carcass composition in live fish (Probert and Shannon, 2000; Veliyulin et al., 2005; Silva et al., 2010a). Comprehensive studies using image techniques such as CT (Romvári et al., 2002; Hancz et al., 2003; Kolstad et al., 2004), MRI (Collewet et al., 2001; Veliyulin et al., 2005) and RTU (Bosworth et al., 2001; Rodrigues et al., 2010; Silva et al., 2010a) have shown that these techniques are able to predict carcass traits in fish. From a practical point of view, CT has several characteristics that make it the preferred technique for in vivo evaluation of carcass composition in fish. In fact, RTU is a simple, rapid and reasonably priced technique (Stouffer, 2004). Additionally, as water is an excellent coupling medium between transducer and fish, the RTU images can be captured when the fish are in the water (Crepaldi et al., 2006). Over the years, this technique has been shown to be sufficiently precise and accurate to be used as a tool for carcass composition studies (e.g., De Campeneere et al., 2001). Despite these attributes, little information is available about the use of RTU to predict carcass composition in fish. Examples of studies that use RTU images to predict fish carcass composition traits are summarized in Table 11.6.

The results of these studies are reliable. In farm-raised catfish, Bosworth et al. (2001) reported that ultrasound measurements of muscle area in live fish are strongly correlated with the equivalent measurements take on the carcass $(r=$ $0.84-0.94 ; P<0.001$ ), but in meat yield measurements there was only moderate correlation between the two. A single transverse ultrasound scan accounted for $40-50 \%$ of the variation in meat yield traits in female catfish, and $16-23 \%$ in male catfish (Bosworth et al., 2001). In the same study, using multiple regressions, Bosworth et al. (2001) found a three-variable model using ultrasound and 
Table 11.6 Examples of studies for predicting fish carcass traits using RTU technique

\begin{tabular}{|c|c|c|c|c|}
\hline Reference & Objective & Results & Equipment & Notes \\
\hline Probert and Shannon (2000) & $\begin{array}{l}\text { Low intensity ultrasound to } \\
\text { determine fish composition, } \\
\text { particularly the fat content }\end{array}$ & Encouraging results & 2.0 MHz convex & Freshly killed fish \\
\hline Bosworth et al. (2001) & $\begin{array}{l}\text { Determine the relationships } \\
\text { between meat yield traits } \\
\text { with body shape traits and } \\
\text { transverse ultrasound images } \\
\text { of muscle area measured in } \\
\text { live catfish }\end{array}$ & $\begin{array}{l}\text { A single ultrasound } \\
\text { measurement } \\
\text { explained } 40-50 \% \\
\text { and } 16-23 \% \text { of the } \\
\text { variation in meat yield } \\
\text { traits of females and } \\
\text { males, respectively } \\
\text { The best three variable } \\
\text { models using } \\
\text { ultrasound and body } \\
\text { shape traits explained } \\
48-56 \% \text { and } 31-38 \% \\
\text { of the variation in meat } \\
\text { yield traits in females } \\
\text { and males, respectively }\end{array}$ & $\begin{array}{l}\text { Toshiba Echocee; } \\
7.5 \mathrm{MHz} \text { convex }\end{array}$ & Fish were tranquilized \\
\hline Bosworth et al. (2001) & $\begin{array}{l}\text { Study with } 30 \text { market weight } \\
\text { channel catfish to compare } \\
\text { muscle area measured from } \\
\text { transverse ultrasound images } \\
\text { with muscle area measured }\end{array}$ & $\begin{array}{l}\text { Correlations between } \\
0.84 \text { and } 0.94 \text { for } \\
\text { ultrasound muscle area } \\
\text { with equivalent carcass } \\
\text { measurement }\end{array}$ & $\begin{array}{l}\text { Aloka 1700; } \\
5 \mathrm{MHz} \text { linear }\end{array}$ & \\
\hline
\end{tabular}


Table 11.6 Continued

\begin{tabular}{|c|c|c|c|c|}
\hline Reference & Objective & Results & Equipment & Notes \\
\hline Silva et al. (2010a) & $\begin{array}{l}\text { Develop a rapid non-destructive } \\
\text { and non invasive method to } \\
\text { predict fillet volume of Solea } \\
\text { senegalensis individuals } \\
\text { from volume measurements } \\
\text { obtained in vivo after RTU } \\
\text { image analysis }\end{array}$ & $\begin{array}{l}\text { The best model explains } \\
98 \% \text { of the fillet } \\
\text { volume variation } \\
\text { and was obtained by } \\
\text { stepwise procedure } \\
\text { with } \mathrm{S} 3, \mathrm{~S} 2 \text { and S4 } \\
\text { cross-sectional slices } \\
\text { volumes }\end{array}$ & $\begin{array}{l}\text { Aloka 500V; } 7.5 \\
\text { MHz linear }\end{array}$ & $\begin{array}{l}\text { Fishes under } \\
\text { anaesthesia }\end{array}$ \\
\hline Rodrigues et al. (2010) & $\begin{array}{l}\text { Relationship between the } \\
\text { traditional solvent-extraction } \\
\text { fat determination method with } \\
\text { RTU measurements }\end{array}$ & $\begin{array}{l}\text { Preliminary results with } \\
\text { RTU images clearly } \\
\text { support the preferential } \\
\text { accumulation of fat in } \\
\text { subcutaneous tissues of } \\
\text { Senegalese sole }\end{array}$ & $\begin{array}{l}\text { Aloka 500V; } 7.5 \\
\text { MHz linear }\end{array}$ & \\
\hline
\end{tabular}




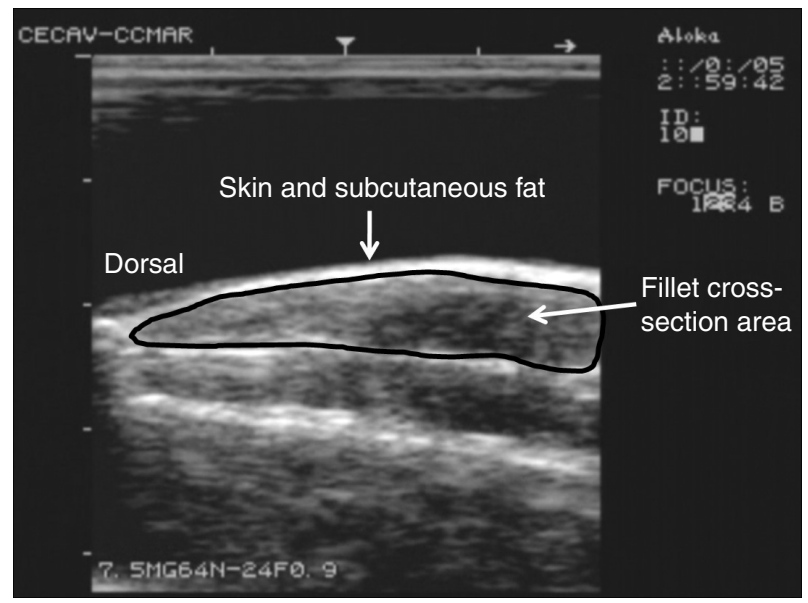

Fig. 11.4 Example of RTU image showing a fillet cross-section area obtained after image analysis.

body shape variables that accounted for $48-56 \%$ and $31-38 \%$ of the variation in meat yield traits in females and males, respectively. On the other hand, Silva et al. (2010a) scanned flat fish (Solea senegalensis) with an RTU ultrasound with a 7.5 $\mathrm{MHz}$ probe to capture ten cross-sectional slices (Fig. 11.4), from which fillet volume measurements were obtained after image analysis. The best model accounted for $98 \%$ of the fillet volume variation and was obtained through volume measurements of three cross-sectional slices.

In fish species processing errors combined with potential errors in RTU image capture and image analysis may limit the accuracy of models for predicting tissues and yield in live fish. For example, fish movement during ultrasound scanning is one drawback that limits the use of RTU in fish farms (Probert and Shannon, 2000). In general, the use of an anaesthetic (Bosworth et al., 2001; Silva et al., 2010a) or, more radically, the use of freshly killed fish (Probert and Shannon, 2000) were reported to reduce fish movement. The need to use these procedures, especially the latter, has restricted the use of this technique in fish farms. Fish size is another limiting factor: the RTU technique is less effective with small fish (Bosworth et al., 2001). However, the use of high-frequency probes $(7.5-10 \mathrm{MHz})$ overcomes this problem because clearer images can be obtained from proximal anatomical structures.

\subsection{Using real-time ultrasonography to predict intramuscular fat (IMF) in vivo}

It is recognized that fat plays an important role in the eating quality of meat (Wood et al., 2008; Kouba and Sellier, 2011). Intramuscular fat (IMF) content, particularly in cattle and swine, affects meat quality, especially the sensory properties of juiciness and flavour (Huff-Lonergan et al., 2002; Thompson, 2004; Skiba, 2010). Some studies have shown that IMF or marbling is essential for meat 
acceptability by consumers (Shi-Zheng and Su-Mei, 2009) and for meat industry grading (Smith et al., 2008a). Before reviewing the use of ultrasound technology to examine these features, the differences between IMF and marbling should be outlined. IMF refers to the chemically extractable fat in a muscle (Shi-Zheng and Su-Mei, 2009) and is an objective measurement, whereas marbling, assessed visually, refers to the appearance of evenly distributed white flecks or streaks of fatty tissue between bundles of muscle fibres (Tume, 2004) and can be subjectively assessed with grading scores or objectively assessed when image analysis is used (e.g., Faucitano et al., 2005; Jackman et al., 2008). Both are relevant for meat quality evaluation and are closely related to each other (correlation coefficients of up to 0.8 in Savell et al., 1986; Devitt and Wilton, 2001; Kemp et al., 2002). In general, the percentage of IMF is taken as the reference trait (Brethour, 1994), while marbling proves useful in understanding the size and distribution of IMF deposit in meat (Ferguson, 2004). These attributes are relevant and reinforce the value of using image analysis techniques to evaluate marbling (Du et al., 2008).

The IMF trait has been extensively studied in swine and cattle (Pethick et al., 2006). It is now generally agreed that the IMF content accounts for a significant amount of the genetic variation in the eating quality of meat of these species (Shi-Zheng and Su-Mei, 2009; Schwab et al., 2009, 2010). In addition, IMF is one of the meat quality traits that has the potential to be measured in live animals (Newcom et al., 2002; Aass et al., 2009). Thus, a cost-effective and accurate method for quantifying IMF in vivo is needed, because repeated measurements are necessary on one animal, if it is intended for breeding (Williams, 2002; Parnell, 2004). Furthermore, it is possible to establish the optimal point at which the animal should be sold with the greatest economic benefit (Houghton and Turlington, 1992; Rimal et al., 2006). To achieve this goal, experimental work was conducted to predict IMF in vivo through RTU and image analysis (e.g., Brethour, 1990; Amin et al., 1997). This technique was found to be particularly promising since it is relatively cheap, easy to use and animal-friendly (Stouffer, 2004). Even though the majority of the studies using ultrasonography to estimate the percentage of IMF date from the 1990s (e.g., Brethour, 1990; Sather et al., 1996), the technique has been used since the 1960s to estimate fat thickness in the back and the rib eye area, and by then it was already perceived as a technique with the potential for use in IMF prediction (Hedrick et al., 1962; Davis et al., 1964).

The use of ultrasound image analysis to predict marbling in beef cattle was first attempted by Haumschild and Carlson (1983). This study had only marginal success and was considered too inefficient to have any practical significance. Later on, a number of authors (e.g., Brethour, 1994; Hassen et al., 1999b; Newcom et al., 2002) reported results which undoubtedly suggest that IMF was accurately predicted with RTU and image analysis.

In the early 1990s, Wilson (1992) stated that considerable research and development was needed before ultrasound could be effectively employed in cattle production and breeding. Since then, ultrasound technology has become a well-established and widely accepted method for predicting IMF in live cattle and swine (i.e., Brethour, 1994; Herring et al., 1998; Hassen et al., 1999b, 2001; Chambaz et al., 
2002; Newcom et al., 2002; Bahelka et al., 2009; Schwab et al., 2010). Recently, the RTU technology for predicting IMF was chosen as one of the 100 Innovations from Academic Research to Real-World Application (AUTM, 2007). This report recognized the work developed by Professor John Brethour from Kansas State University, which changed the beef industry by allowing producers to employ a cost-efficient method for measuring intramuscular fat in livestock. Nonetheless, ultrasound technology can still be further optimized for IMF prediction, by improving RTU image analysis and image acquisition (Shi-Zheng and Su-Mei, 2009).

\subsubsection{Using RTU image analysis for IMF prediction}

The IMF is primarily determined by the distribution pattern of fat flecks in a crosssection of the LTL muscle, usually between the 12th and the 13th thoracic vertebrae (Fig. 11.5a). Although IMF is present in other muscles, the assessment generally is performed on a LTL muscle section. The IMF consists of deposits that occur within the muscle, which are irregular either in form or in their dispersal. These deposits represent a cluster of IMF cells. Individual cells can be very small (40-60 $\mu \mathrm{m})$ and are not visible to the human eye (Anon., 2004). The rough surface and small size of IMF deposits cause sound waves to scatter (Brethour, 1990; Whittaker et al., 1992), producing spots on RTU images that are referred to as speckles (Fig. 11.5b). This is why ultrasound techniques have the potential to predict IMF in vivo after RTU image analysis (Brethour, 1990; Whittaker et al., 1992).

The RTU image analysis for predicting IMF or marbling has been carried out in a number of ways over the years. Early studies were conducted to predict marbling scores from a subjective analysis of the RTU image features (coherent speckle, attenuating and reverberation) from which a speckle score was obtained (Harada and Kumazaki, 1979; Brethour, 1990). Speckle scores were estimated visually and corresponded subjectively to a point classification scheme. This procedure had the benefit of allowing an immediate estimation of the marbling score and, thanks to the portability of the ultrasound equipment portability, could be used for farm animals (Brethour, 1990). However, it is subjective, and dependent on beam geometry and machine calibration. Furthermore, an understanding of the classification scheme and calculation of the score can be difficult for a technician to acquire (Brethour, 1990). These negative aspects led Brethour (1990) to observe that ultrasound speckle was a 'quick and dirty' way to estimate the marbling score of a carcass and that, consequently, further improvements were necessary to reduce the subjectivity of RTU images. Although a skilled ultrasound technician can visually interpret an RTU image and estimate marbling in a live animal with fair accuracy (Brethour, 1990, 1994), it was recognized that research using mathematical models for RTU image analysis was imperative (Amin et al., 1993; Kim et al., 1998).

\subsubsection{Mathematical modelling approaches from RTU image analysis}

Since the early studies (Harada and Kumazaki, 1979; Brethour, 1990), several papers have dealt with the assessment of IMF content and marbling by RTU 
(a)

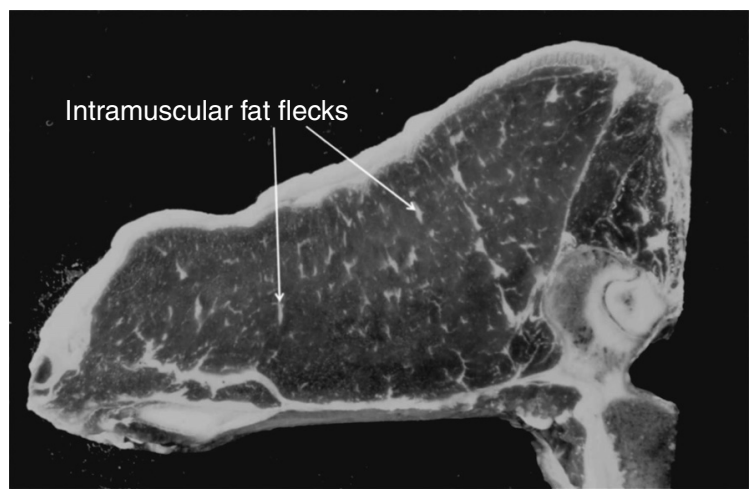

(b)

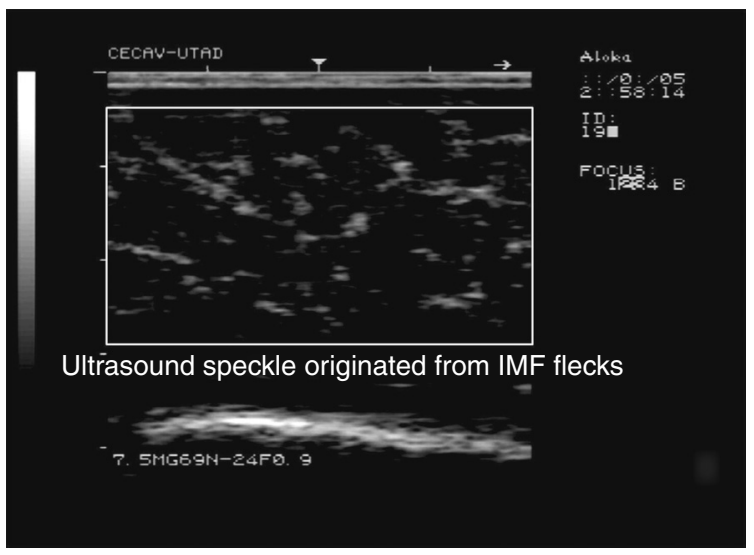

Fig. 11.5 (a) Image from a cattle lumbar cut section showing LTL muscle and intramuscular fat flecks and (b) RTU image of the LTL muscle showing speckle originated from IMF.

computer image analysis (Brethour, 1994; Hassen et al., 2001; Harron and Dony, 2009). On the whole, results obtained with mathematical procedures were superior to the subjective RTU image evaluation, even when this task was conducted by an experienced individual (Raeth et al., 1985; Couto et al., 2011). Since the first attempt was made to predict IMF using RTU image analysis, significant advances have been possible as a result of developments in equipment and software. Table 11.7 summarizes some studies that have used RTU images to predict IMF and marbling score.

The algorithms used to predict the IMF percentage of live animals were based on regression analysis (Whittaker et al., 1992; Amin et al., 1993; Newcom et al., 2002; Li et al., 2009); neural network (Brethour, 1994; Amin et al., 1992; Harron and Dony, 2009; Li et al., 2009) or support vector machine (Harron and Dony, 2009), among others. These algorithms were developed from textural RTU image features such as a histogram of pixel grey levels, Fourier-based 
Table 11.7 Summary of trials to predict intramuscular far percentage or marbling score from RTU image analysis in cattle and swine

\begin{tabular}{|c|c|c|c|c|c|c|c|c|c|c|}
\hline Reference & $\begin{array}{l}\text { RTU } \\
\text { equipment }\end{array}$ & Probe & $n$ & Species & $\begin{array}{l}\text { Anatomical } \\
\text { position }\end{array}$ & $\mathrm{Y}$ & $\mathrm{X}$ & $r^{2}$ & RSD & $\begin{array}{l}\text { Statistical } \\
\text { analysis }\end{array}$ \\
\hline $\begin{array}{l}\text { Brethour } \\
(1990)\end{array}$ & Aloka 210 & $\begin{array}{l}3 \mathrm{MHz}, \\
107 \mathrm{~mm}\end{array}$ & 40 & Cattle & $\begin{array}{l}\text { 12th rib, } \\
\text { parallel and } \\
\text { perpendicular }\end{array}$ & $\begin{array}{l}\text { Marbling } \\
\text { score }\end{array}$ & $\begin{array}{l}\text { Speckle } \\
\text { patterns }\end{array}$ & 0.45 & $0.36 \%$ & Regression \\
\hline Amin et al. & Aloka 500 & $\begin{array}{l}3.5 \mathrm{MHz}, \\
172 \mathrm{~mm}\end{array}$ & 126 & Cattle & $\begin{array}{l}\text { Across } 12 \text { th and } \\
13 \text { th ribs }\end{array}$ & $\mathrm{IMF} \%$ & $\begin{array}{c}\text { Image texture } \\
\text { features }\end{array}$ & & $\begin{array}{l}1.39 \text { and } \\
1.42 \%\end{array}$ & Regression \\
\hline $\begin{array}{l}\text { Brethour } \\
\text { (1994) }\end{array}$ & Aloka 210 & $\begin{array}{l}3.5 \mathrm{MHz}, \\
125 \mathrm{~mm}\end{array}$ & $\begin{array}{c}53 \text { and } \\
108\end{array}$ & Cattle & $\begin{array}{l}\text { 12th rib, } \\
\text { parallel and } \\
\text { perpendicular }\end{array}$ & $\begin{array}{l}\text { Marbling } \\
\text { score }\end{array}$ & $\begin{array}{l}\text { Image texture } \\
\text { features }\end{array}$ & 0.53 & & $\begin{array}{l}\text { Neural } \\
\text { network }\end{array}$ \\
\hline $\begin{array}{l}\text { Kim et al. } \\
\text { (1998) }\end{array}$ & Aloka 500 & $\begin{array}{l}3.5 \mathrm{MHz}, \\
125 \mathrm{~mm}\end{array}$ & 207 & Cattle & $\begin{array}{l}\text { Across the } 11 \text { th } \\
\text { and } 13 \text { th rib }\end{array}$ & $\mathrm{IMF} \%$ & $\begin{array}{l}\text { Image texture } \\
\text { features }\end{array}$ & & $1.4 \%$ & \\
\hline $\begin{array}{l}\text { Hassen et al. } \\
\qquad(1999 b)\end{array}$ & Aloka 500 & $\begin{array}{l}3.5 \mathrm{MHz}, \\
172 \mathrm{~mm}\end{array}$ & 144 & Cattle & $\begin{array}{l}\text { Across } 11 \text { th } \\
-13 \text { th ribs }\end{array}$ & & & & & \\
\hline $\begin{array}{l}\text { Hassen et al. } \\
\quad(2001)\end{array}$ & Aloka 500 & $\begin{array}{l}3.5 \mathrm{MHz}, \\
172 \mathrm{~mm}\end{array}$ & 500 & Cattle & $\begin{array}{l}\text { Across the } 11 \text { th } \\
\text { and } 13 \text { th rib }\end{array}$ & $\mathrm{IMF} \%$ & $\begin{array}{c}\text { Image texture } \\
\text { features }\end{array}$ & 0.72 & $0.84 \%$ & Regression \\
\hline $\begin{array}{l}\text { Hassen et al. } \\
\qquad(2001)\end{array}$ & Pie 200 & $\begin{array}{l}3.5 \mathrm{MHz}, \\
180 \mathrm{~mm}\end{array}$ & 500 & Cattle & $\begin{array}{l}\text { Across the } 11 \text { th } \\
\text { and } 13 \text { th rib }\end{array}$ & $\mathrm{IMF} \%$ & $\begin{array}{l}\text { Image texture } \\
\text { features }\end{array}$ & 0.70 & $0.85 \%$ & Regression \\
\hline $\begin{array}{l}\text { Chambaz et } \\
\text { al. }(2002)\end{array}$ & Pie 200 & $\begin{array}{l}3.5 \mathrm{MHz}, \\
180 \mathrm{~mm}\end{array}$ & & Cattle & $\begin{array}{l}\text { Across } 12 \text { th and } \\
13 \text { th ribs }\end{array}$ & $\mathrm{IMF} \%$ & $\begin{array}{l}\text { RTU, hide } \\
\text { thickness and } \\
\text { liveweight }\end{array}$ & & $0.96 \%$ & Regression \\
\hline $\begin{array}{l}\text { Aass et al. } \\
\qquad(2006)\end{array}$ & Pie 200 & $\begin{array}{l}3.5 \mathrm{MHz}, \\
180 \mathrm{~mm}\end{array}$ & 145 & Cattle & $\begin{array}{l}\text { 12th thoracic } \\
\text { and 1st } \\
\text { lumbar } \\
\text { vertebrae }\end{array}$ & $\mathrm{IMF} \%$ & $\begin{array}{l}\text { Image texture } \\
\text { features }\end{array}$ & 0.48 & $0.46 \%$ & Regression \\
\hline $\begin{array}{l}\text { Aass et al. } \\
\qquad(2009)\end{array}$ & Pie 200 & $\begin{array}{l}3.5 \mathrm{MHz}, \\
180 \mathrm{~mm}\end{array}$ & 172 & Cattle & $\begin{array}{c}\text { 12th thoracic } \\
\text { and } 1 \mathrm{st} \\
\text { lumbar } \\
\text { vertebrae }\end{array}$ & $\mathrm{IMF} \%$ & $\begin{array}{l}\text { Image texture } \\
\text { features }\end{array}$ & 0.80 & $0.66 \%$ & Regression \\
\hline
\end{tabular}


Table 11.7 Continued

\begin{tabular}{|c|c|c|c|c|c|c|c|c|c|c|}
\hline Reference & $\begin{array}{l}\text { RTU } \\
\text { equipment }\end{array}$ & Probe & $n$ & Species & $\begin{array}{l}\text { Anatomical } \\
\text { position }\end{array}$ & $\mathrm{Y}$ & $X$ & $r^{2}$ & RSD & $\begin{array}{l}\text { Statistical } \\
\text { analysis }\end{array}$ \\
\hline $\begin{array}{l}\text { Harron and } \\
\text { Dony } \\
\text { (2009) }\end{array}$ & Aloka 500 & $\begin{array}{l}3.5 \mathrm{MHz} \\
172 \mathrm{~mm}\end{array}$ & 75 & Cattle & $\begin{array}{l}\text { Across } 12 \text { th and } \\
\text { 13th }\end{array}$ & $\mathrm{IMF} \%$ & $\begin{array}{l}\text { Image texture } \\
\text { features }\end{array}$ & & $1.37 \%$ & $\begin{array}{l}\text { Recursive } \\
\quad \text { least } \\
\text { squares } \\
\text { filter }\end{array}$ \\
\hline $\begin{array}{l}\text { Harron and } \\
\text { Dony } \\
\text { (2009) }\end{array}$ & Aloka 500 & $\begin{array}{l}3.5 \mathrm{MHz} \\
172 \mathrm{~mm}\end{array}$ & 75 & Cattle & $\begin{array}{l}\text { Across } 12 \text { th and } \\
\text { 13th }\end{array}$ & $\mathrm{IMF} \%$ & $\begin{array}{l}\text { Image texture } \\
\text { features }\end{array}$ & & $2.67 \%$ & $\begin{array}{l}\text { Support } \\
\text { vector } \\
\text { machine }\end{array}$ \\
\hline $\begin{array}{l}\text { Harron and } \\
\text { Dony } \\
\text { (2009) }\end{array}$ & Aloka 500 & $\begin{array}{l}3.5 \mathrm{MHz}, \\
172 \mathrm{~mm}\end{array}$ & 75 & Cattle & $\begin{array}{l}\text { Across } 12 \text { th and } \\
13 \text { th }\end{array}$ & $\mathrm{IMF} \%$ & $\begin{array}{l}\text { Image texture } \\
\text { features }\end{array}$ & & $1.36 \%$ & $\begin{array}{l}\text { Linear neural } \\
\text { network }\end{array}$ \\
\hline $\begin{array}{l}\text { Harron and } \\
\text { Dony } \\
\text { (2009) }\end{array}$ & Aloka 500 & $\begin{array}{l}3.5 \mathrm{MHz}, \\
172 \mathrm{~mm}\end{array}$ & 75 & Cattle & $\begin{array}{l}\text { Across } 12 \text { th and } \\
\text { 13th }\end{array}$ & $\mathrm{IMF} \%$ & $\begin{array}{l}\text { Image texture } \\
\text { features }\end{array}$ & & $1.36 \%$ & $\begin{array}{l}\text { Multilayer } \\
\text { perceptron } \\
\text { network }\end{array}$ \\
\hline $\begin{array}{l}\text { Sather et al. } \\
\text { (1996) }\end{array}$ & LS-1000 & $3.5 \mathrm{MHz}$ & 149 & Swine & $\begin{array}{l}\text { 3rd and 4th } \\
\text { lumbar }\end{array}$ & $\mathrm{IMF} \%$ & $\begin{array}{l}\text { Percent object } \\
\text { area of } \\
\text { muscle }\end{array}$ & 0.012 & & Regression \\
\hline $\begin{array}{l}\text { Sather et al. } \\
\text { (1996) }\end{array}$ & CS-3000 & $3.5 \mathrm{MHz}$ & 240 & Swine & $\begin{array}{l}\text { 3rd and 4th } \\
\text { lumbar }\end{array}$ & $\mathrm{IMF} \%$ & $\begin{array}{l}\text { Percent object } \\
\text { area of } \\
\text { muscle }\end{array}$ & 0.04 & & Regression \\
\hline $\begin{array}{l}\text { Newcom et al. } \\
\quad(2002)\end{array}$ & Aloka 500 & $\begin{array}{l}3.5 \mathrm{MHz} \\
125 \mathrm{~mm}\end{array}$ & 207 & Swine & $\begin{array}{l}\text { Across } 10 \text { th to } \\
\text { the } 13 \text { th ribs }\end{array}$ & $\mathrm{IMF} \%$ & $\begin{array}{l}\text { Image texture } \\
\text { features }\end{array}$ & 0.32 & $1.02 \%$ & \\
\hline $\begin{array}{l}\text { Bahelka et al. } \\
\text { (2009) }\end{array}$ & Aloka 500 & $\begin{array}{l}3.5 \mathrm{MHz}, \\
172 \mathrm{~mm}\end{array}$ & 144 & Swine & Last rib & $\mathrm{IMF} \%$ & & 0.38 & $0.52 \%$ & Regression \\
\hline $\begin{array}{l}\text { Schwab et al. } \\
\quad(2010)\end{array}$ & Aloka 500 & $\begin{array}{l}3.5 \mathrm{MHz}, \\
125 \mathrm{~mm}\end{array}$ & & Swine & $\begin{array}{l}\text { Across the } 10 \text { th } \\
\text { to } 13 \text { th ribs }\end{array}$ & $\mathrm{IMF} \%$ & $\begin{array}{l}\text { Image texture } \\
\text { features }\end{array}$ & 0.81 & & Regression \\
\hline
\end{tabular}


parameters, gradient-based parameters and co-occurrence parameters (Amin et al., 1997; Hassen et al., 1999b; Newcom et al., 2002; Harron and Dony, 2009). Generally, image features can be calculated after selecting a region of interest (ROI) over the RTU image; the image analysis software then provides an ROI parameter file with the image parameters (Amin et al., 1997; Silva et al., 2010b).

In parallel to research on RTU image analysis for IMF evaluation, several studies aimed at establishing practical and usable software image analysis for livestock production (Amin et al., 1997; Aass et al., 2006). For example, the software proposed by Amin et al. (1997) was frequently used in both swine (Newcom et al., 2002; Schwab et al., 2010) and cattle (Hassen et al., 1999b). An RTU image acquisition protocol must be followed in order to use this software. For swine, a minimum of four longitudinal images were collected at $7 \mathrm{~cm}$ offmidline across the 10th-13th ribs (Newcom et al., 2002; Schawab et al., 2009, 2010). With cattle, four to six images were taken longitudinally without a wave guide (standoff block) across the 11th-13th ribs of the animal at a position threequarters of the distance from the medial end of the rib eye area to the lateral end (Hassen et al., 1999b, 2001). Currently, most swine and cattle scanning for IMF prediction is carried out using an Aloka $500 \mathrm{~V}$ with a $17 \mathrm{~cm}$ linear array $3.5 \mathrm{MHz}$ transducer (e.g., Hassen et al., 2001; Newcom et al., 2002; Schawab et al., 2010) or with a Pie $200 \mathrm{SLC}$ with a $18 \mathrm{~cm}$ linear array $3.5 \mathrm{MHz}$ transducer (e.g., Aass et al., 2009). In either case, ultrasound images of the highest quality must be collected. In fact, it is well established that image quality has an impact on measurement accuracy (Houghton and Turlington, 1992; Spangler and Moser, 2009). For both swine and cattle, a typical image with acceptable quality includes the following features: clearly visible hide and subcutaneous fat layer(s) without any sign of uneven couplant or poor transducer contact; LTL muscle area taken from across the 10th-13th ribs with clearly visible rib-shadows; even speckle or texture pattern in the muscle area; and ROI box area completely free of deficiencies (Amin et al., 1997; Hassen et al., 1999b; Newcom et al., 2002). It is also important to correctly distinguish the various tissue types - subcutaneous fat, muscle, blood capillaries, intramuscular fat and bones - for ROI box selection and subsequent use of computer image analysis (Amin et al., 1997). During the image analysis process, attention must be paid to all these aspects since they affect the nature of the ultrasonic backscattered signal and consequently the quality of the image (Amin et al., 1992). For each image, parameters were generated using texture analysis from a $100 \times 100$ pixels ROI box (Amin et al., 1997; Hassen et al., 2001; Newcom et al., 2002).

Two observations may be made on the basis of the reports on RTU image analysis and IMF presented in Table 11.7. First, the developments in ultrasound technology offer an opportunity to better predict carcass and meat quality with regard to IMF. Second, the developing technology of using ultrasound image analysis for IMF prediction has been successfully transferred from research to the beef and swine industry, which has allowed improvements in carcass quality. 


\subsection{Optimization of production system and market carcass characteristics}

The most important attribute of meat quality is its overall eating satisfaction, which is a function of the combined effects of tenderness, juiciness and flavour (Ferguson, 2004). However, today's meat is usually criticized for its lack of succulence, due to the low levels of intramuscular fat (marbling), which has been the outcome of years of genetic selection that has aimed to reduce the fat content of the carcass. Moreover, the slaughtering of animals either before or after the optimum point is responsible for significant economic losses (Brethour, 2000), and the prediction of the optimum slaughter date is key in maximizing the quality of the meat and the income of the producer (Williams, 2002). RTU can be used to develop a decision support system to sort animals into management groups prior to feedlot feeding, and to predict the optimum slaughter point using computerbased models to assist the management decisions.

\subsubsection{Predicting optimum slaughter date}

Meat tenderness and juiciness are positively correlated with the proportion of fat in the carcass (Wood, 1990; Bruns et al., 2004). Marbling fat has no direct effect on meat tenderness (Renand et al., 2003; Thompson, 2004); however, it plays an important role in meat juiciness and overall eating satisfaction. In fact, marbling leads to greater palatability in panel scores (McPeake, 2001) and lower shear force values (Dolezal et al., 1982). Carcasses with higher marbling content also have a higher subcutaneous and intermuscular fat content, thus insulating the muscles during chilling and preventing the phenomenon of cold shortening.

The production of carcasses with excessive weight, excessive subcutaneous fat and only a small degree of marbling, as well as a lack of uniformity, is a common problem in meat production systems. The production of carcasses with the correct weight and an optimum amount of subcutaneous fat therefore ensures that the meat is protected during the cooling process and also maximizes the organoleptic properties.

Fatter carcasses undergo a faster drop in $\mathrm{pH}$, which is associated with more tender meat; and slower cooling of fatter carcasses contributes to an increase in the activity of ageing enzymes, leading to greater tenderness (Wood, 1995). Even under normal chilling conditions, carcasses with less than $13 \mathrm{~mm}$ of SFD over LTL display reduced tenderness due to the cold shortening effect (Wood, 1995). Ageing a carcass affected by cold shortening will not alleviate the detrimental effects on tenderness. Thus, the SFD is a very important attribute, because it protects the meat from thermal shock during refrigeration, which prevents cold shortening, oxidation of muscles, browning and microbial contamination of meat during skinning.

As stated previously, the ability to measure the SFD, LMA and marbling using ultrasound images taken from live animals provides an opportunity to study the relationship between animal growth and the development of various tissue types. 
Thus, for a known feeding strategy, it is possible to monitor the growth of SFD and LMA and the deposition of marbling as the animals grow and during the finishing phase. These data can then be used to project the slaughter date, for a pre-defined subcutaneous fat level (Brethour, 2000). For example, Delehant et al. (1996) showed that ultrasound measures, taken on cattle prior to feedlot feeding, combined with performance data collected during the finishing phase, could effectively predict LMA, SFD and IMF percentage at any point during the finishing phase. The ability to predict the optimum slaughter date of a particular animal is an attractive use of ultrasound technology (Lusk et al., 2003). The RTU can be used to develop models to predict the number of days necessary to reach a target carcass composition under a defined feeding regime (Hassen et al., 1999a), or to develop a feeding regime that maximizes the production of carcasses with a higher-yield or higher-quality grade (Basarab et al., 1999).

So far, the use of RTU to optimize the slaughter date has been focused on beef production; however, RTU can also be successfully used for meat species such as swine. RTU is also useful in predicting market-weight slaughter characteristics and in predicting the percentage of lean cuts in market-weight swine. The ability to predict market-weight slaughter characteristics was investigated by Robinson et al. (1992). Similarly, McLaren et al. (1989) studied 110 barrows and gilts, which were scanned every two weeks from 42 days old up to the point of slaughter to measure SFD at the first rib, last rib and last lumbar vertebrae, and to measure LMA at the 10th rib. They showed that ultrasound measurements were able to estimate lean gain a day early (up to $53 \mathrm{~kg} \mathrm{BW}$ ) immediately prior to slaughter. These authors (McLaren et al., 1989) concluded that ultrasound data were useful in early selection decisions and for selections made at market weight for carcass merit in swine. Olsen et al. (2007) also used ultrasound for online classification of swine carcasses and showed that live animal ultrasound measurements could predict retail product yield after slaughter.

The implementation of RTU in meat production systems can help to reduce the production of carcasses with either too little or too much subcutaneous fat. This is beneficial for producers - first, as it can lead to reduced feeding costs, and also because it improves the quality of the product presented to consumers.

\subsubsection{Sorting animals prior to feedlot feeding}

The study by Green et al. (2000) found a total of 280 inefficiencies in the US beef industry, and proved that the majority of losses occurred due to excessive fat production, leading to poor consistency in taste. Green et al. (2000) concluded that the beef cattle industry needed to improve carcass quality by improving feeding and management practices, as well as by genetic improvement.

Ultrasound technology provides information on the optimum sorting of animals into feedlot groups, based on their body composition predicted by RTU measurements of SFD at the 12th rib level (Houghton and Turlington, 1992; Hassen et al., 1999a). This approach for beef cattle was shown to be more accurate than simple visual appraisal (Delehant et al., 1996). Sorting meat animals into uniform groups based on frame size, SFD and LMA can help to obtain carcasses with 
uniform slaughter weight and consistent composition, which can then be sold at the optimal time (Houghton and Turlington, 1992; Wall et al., 2004; Rimal et al., 2006). When cattle have an average initial SFD of more than $3 \mathrm{~mm}$, ultrasound is useful in projecting the number of days required to reach a target SFD level, which allows animals to be clustered into groups for more effective marketing (Brethour, 2000).

Ultrasound provides information about the carcass of each animal individually, and if the data are collected when animals start on feed, it can also provide information that can be used to sort animals into adequate feeding regimes (Lusk et al., 2003). Therefore, RTU contributes to reducing the problem of overfeeding, improves the efficiency of the production system and increases the income of the meat producers (Lusk et al., 2003; Pyatt et al., 2005). For example, Basarab et al. (1999) used ultrasound to sort beef cattle three to four months before slaughter into more uniform groups, and this strategy displayed positive effects on growth rate, feed efficiency, carcass yield and quality grade, as well as increasing the net return by $\$ 15-\$ 27$ per head slaughtered. Similarly, with swine, Gresham et al. (1992) showed that RTU was able to separate either live animals or carcasses using a single SFD measurement along with live or carcass weight. Gresham et al. (1992) concluded that RTU can be used in a commercial environment to achieve accurate measurements of carcass value or of compositional differences between the carcasses.

Variation among cattle within a pen diminishes opportunities for precision feeding. If cattle within a pen are more uniform in their characteristics, they can be fed more precisely according to requirements; this is preferable to using an average measurement to determine feeding, as this can overfeed or underfeed a portion of the cattle (Trenkle and Williams, 1997). The costs and the labour required to operate the system remain the main barriers to the adoption of this technology (Basarab et al., 1999). However, recent developments in ultrasound equipment, along with remote sensing and infrared technologies, may make the system of sorting cattle for feeding purposes completely non-invasive and also less labour intensive $\mathrm{Li}, 2010$.

\subsubsection{Optimizing marketing strategies}

A genuine value-based marketing system will necessarily result in some premiums as well as discounts (Trenkle and Williams, 1997); management optimization can contribute to increased economic returns and carcass desirability in the marketplace. The optimization of management can include strategies such as energy concentration in the diets used during growth and in the finishing phase, and the length of feeding, among many others. However, the prediction of carcass composition pre-slaughter allows the identification of animals with higher carcass cutability (Paisley et al., 2007), and beef producers are able to provide carcasses according to consumer preferences (Williams and Trenkle, 1997). Thus, RTU will enhance the profitability of meat producers, as it will allow them to raise meat animals that directly correspond to the desired attributes of consumers 
(Rimal et al., 2006). The ultrasound data collected from live animals can be used to predict carcass yield and quality grades (Lusk et al., 2003), and to enhance the meat marketing decisions by optimally targeting carcasses to specific market needs. Lusk et al. (2003) studied the potential use of ultrasound measurements taken in the feedlot in guiding pricing decisions for cattle. They found that actual carcass merits were reasonably accurately predicted; and that when cattle were sorting for live, dressed, or grid-based pricing, an increase of returns of $\$ 25$ per head was achieved compared with marketing all cattle on a live-weight basis.

\subsection{The future of RTU imaging in the meat industry}

There have been remarkable achievements in the development of ultrasound as a tool for the prediction of carcass composition and meat traits in animals since its first application in the late 1950s. The advent of RTU and image analysis have made ultrasound a valuable and reliable tool in animal research and production, with major applications in genetics, nutrition, carcass value-based marketing and monitoring for body fat reserves (Moeller, 2002; Williams, 2002; Parnell, 2004; Schröder and Staufenbiel, 2006). For all these applications, ultrasound technology will continue to expand as a tool for management practices that affect the productivity and profitability of the meat industry (Moeller, 2002; Li, 2010). One good example of this is the use of ultrasound technology, coupled with current selection methods and molecular tools, to speed up genetic progress in meat traits (MacNeil et al., 2010; Nalaila et al., 2011). Despite the impressive advances in ultrasound systems, mainly in the last decade for all meat species, some technological aspects have the potential for further improvement in the near future. As in the past, current developments in ultrasound technology originate in the field of medicine, particularly from the very dynamic and expanding field of image diagnostics (Stouffer, 2004; Thompson, 2010). Although the needs of the medical sector are quite different from those of the animal science sector, the same medical ultrasound equipment can still be easily used animal science protocols (Stouffer, 2004). Therefore, some of the developments in the medical field may be potentially useful for animal science too. Increasing ultrasound processing capability (King, 2006; Wells, 2006), improvements in image quality (Szabo, 2004; Smith et al., 2008b; Whitsett, 2009), better portability (Ault and Rosen, 2010; Thompson, 2010; Bret et al., 2011), capacity for online analysis and image storage (Whitsett, 2009; Li, 2010) and reduction of equipment and operational costs (Szabo, 2004) are the features that will have the biggest impact on the evaluation of carcass composition and meat traits. In fact, these improvements will allow an increase in the speed of the RTU data collection process either on the farm or at the slaughterhouse. Additionally, faster image analysis and accurate results lead to more information being available along the entire production chain (from stable to table), which helps the industry to better understand and accurately describe the meat products, hence driving improvements in meat quality and productivity (Bindon, 2002; Li, 2010). 


\section{Computer vision technology in the food and beverage industries}

\subsubsection{Prospects for the development of novel ultrasound scanning techniques}

Advances in ultrasound such as synthetic aperture focusing, also known as zone sonography (Wells, 2000; Lyons, 2004), and elastrography (O'Brien and Holmes, 2007; Whitsett, 2009) are likely to be employed in animal science in the future. The zone sonography technology allows faster image acquisition and high image quality, which will prove particularly useful in situations in which multiple images of a subject are required during a scanning session. Elastrography is a technology with the potential to improve the accuracy with which marbling can be predicted. The use of three-dimensional (3-D) ultrasonography is another imaging technique with promising applications in the evaluation of carcass composition and meat traits. As stated by several authors (Mitchell et al., 2001; Kvame and Vangen, 2006; Monziols et al., 2006; Alston et al., 2009), the use of volume measurements, along with image techniques such as MRI and CT, is an attractive approach for predicting carcass composition and meat traits. Although 3-D ultrasound is more costly than conventional ultrasound, it is not prohibitively expensive when incorporated into large breeding programmes.

Despite the impressive advances in ultrasound systems, the software and algorithms still need to be constantly reviewed, and comparisons between systems will still be necessary to find the most suitable means of predicting carcass composition and meat traits for all producing species (Williams, 2002). Future developments in molecular genetics, together with more efficient data collection and dissemination using web-based databases, will increase the value of RTU technology for acquiring information on carcass composition and meat traits (MacFarlane and Simm, 2008; Bertrand, 2009).

\subsection{Conclusion}

Real-time ultrasonography imaging is a versatile and dynamic technology with many current and potential applications in animal science research and animal production. The attributes of the RTU technique have led to its current widespread use in animal science for the in vivo prediction of carcass composition and meat traits in several species. The results obtained with RTU are likely to play a major role in the meat industry by providing accurate and objective carcass and meat traits information in live animals. In the future, it is probable that modern ultrasound techniques will continue to be used in animal science, bringing about further advances in value-based marketing and in precision meat production systems. Research will be focused on developments in ultrasound practicability, portability, cost and public acceptability, and the rapidly advancing field of molecular genetics and the dissemination of web-based databases will further expand the capabilities of RTU as a tool for evaluating carcass composition and meat traits. 


\subsection{References}

Aass, L., Gresham, J. D. and Klemetsdal, G. (2006) Prediction of intramuscular fat by ultrasound in lean cattle. Livestock Science, 101, 228-41.

Aass, L., Fristedt, C. G. and Gresham, J. D. (2009) Ultrasound prediction of intramuscular fat content in lean cattle. Livestock Science, 125, 177-86.

Allen, P. (1990) Measuring body composition in live meat animals. In Wood, J. D. and Fisher, A. V. (eds), Reducing Fat in Meat Animals. London: Elsevier, 201-54.

Alliston, J. C. (1980) Evaluation of carcass quality in live animal. In Haresign, W. (ed.), Sheep Production. London: Butterworth, 75-96.

Alston, C. L., Mengersen, K. L. and Gardner, G. E. (2009) A new method for calculating the volume of primary tissue types in live sheep using computed tomography scanning. Animal Production Science, 49, 1035-42.

Amin, V. (1995) An Introduction to Principles of Ultrasound. Study guide, Iowa State University.

Amin, V. R., Doerr, V. J., Ani, P. R. and Carlson, D. L. (1992) Application of neural network to ultrasound tissue characterization using backscattered signal parameters. Proceedings of the IEEE Medical Imaging Conference, Orlando, Florida, 1357-9.

Amin, V., Roberts, V. R., Patel, A., Wilson, D. and Rouse, G. (1993) Tissue characterization for beef grading using texture analysis of ultrasonic images. Proceedings of the IEEE Ultrasonics Symposium, 2, 969-72.

Amin, V., Wilson, D. E. and Rouse, G. H. (1997) USOFT: An ultrasound image analysis software for beef quality research beef research report. Beef Research Report AS Leaflet R1437, Iowa State University.

Andersen, B. B., Busk, H., Chadwick, J. P., Cuthbertson, A., Fursey, G. A. J., Jones, D. W., Lewin, P., Miles, C. A. and Owen, M. G. (1983) Comparison of ultrasonic equipment for describing beef carcass characteristics in live cattle (report on a joint ultrasonic trial carried out in the UK and Denmark). Livestock Production Science, 10, 133-47.

Andrassy-Baka, G., Romvári, R., Milisits, G., Suto, Z., Szabo, A., Locsmandi, L. and Horn, P. (2003) Non-invasive body composition measurement of broiler chicken between 4 and 18 weeks of age by computer tomography. Arch Tierernahr, 46, 585-95.

Anon. (2004) Visual assessment of marbling and meat colour, Meat Technology Update Newsletter, 2.

Arceo, M., Fassa, V., Conte, A., Iglesias, G., Demarco, A., Romano, E., Huguet, M., Lamouroux, F., Canet, Z., Binda, V. F., Trasorras, V., Caldevilla, M. and Melo, J. (2009) Prediction of weight and proportion of abdominal fat from live animal measurements in Campero-Inta broilers. Rev Argent Prod Anim, 29, 69-73.

Arthur, J. A. and Albers, G. A. A. (2003) Poultry genetics, breeding and biotechnology. In Muir, W. M. and Aggrey, S. E. (eds), Industrial Perspective on Problems and Issues Associated with Poultry Breeding. Wallingford: CAB International, 1-12.

Ault, M. J. and Rosen, B. T. (2010) Portable ultrasound: the next generation arrives. Critical Ultrasound Journal, 2, 39-42.

AUTM (2007) Ultrasound Technology Helps Maximize Beef Production Technology Transfer Works: 100 Innovations from Academic Research to Real-World Application, Technical Report . Association of University Technology Managers, Better World project, 10.

Bahelka, I., Oravcova, M., Peskovicová, D., Tomka, J., Hanusová, E., Lahucky, R. and Demo, P. (2009) Demo comparison of accuracy of intramuscular fat prediction in live pigs using five different ultrasound intensity levels. Animal, 3, 1205-11.

Basarab, J. A., Brethour, J. R., ZoBell, D. R. and Graham, B. (1999) Sorting feeder cattle with a system that integrates ultrasound backfat and marbling estimates with a model that maximizes feedlot profitability in value-based marketing. Canadian Journal of Animal Science, 79, 327-34. 


\section{Computer vision technology in the food and beverage industries}

Bentsen, H. B. and Sehested, E. (1989) Computerized tomography of chickens. British Poultry Science, 30, 575-85.

Berri, C., Debut, M., Lebihan-Duval, E., Sante-Lhoutellier, V., Hattab, N., Jehl, N. and Duclos, M. J. (2005) Technological quality of broiler breast meat in relation to muscle hypertrophy. Arch Tierz, 48, 131.

Bertrand, J. K. (2009) Using actual and ultrasound carcass information in beef genetic evaluation programs. Revista Brasileira de Zootecnia, 38, 58-63.

Bindon, B. M. (2002) Measuring and managing productivity-what do we know; what do we need?. Proceedings of the World Brahman Congress, Rockhampton, Australia, 1-14.

Bochno, R., Rymkiewicz, J. and Szeremeta, J. (2000) Regression equations for in vivo estimation of the meat content of duck carcasses. British Poultry Science, 41, 313-17.

Bosworth, B. G., Holland, M. and Brazil, B. L. (2001) Evaluation of ultrasound imagery and body shape to predict carcass and fillet yield in farm-raised catfish. Journal of Animal Science, 79, 1483-90.

Boyle, M. (2006) The modern poultry yield (r)evolution. International Poultry Production, 13, 7-11.

Bray, D. E. and McBride, D. (1992) Nondestructive Testing Techniques. New York: John Wiley and Sons.

Bret, P. N., Melnick, E. R. and Li, J. (2011) Portable ultrasound for remote environments, Part I: feasibility of field deployment. Journal of Emergency Medicine, 40, 190-7.

Brethour, J. R. (1990) Relationship of ultrasound speckle to marbling score in cattle. Journal of Animal Science, 68, 2603-13.

Brethour, J. R. (1992) The repeatability and accuracy of ultrasound in measuring backfat of cattle. Journal of Animal Science, 70, 1039-44.

Brethour, J. R. (1994) Estimating marbling score in live cattle from ultrasound images using pattern recognition and neural network procedures. Journal of Animal Science, 72, 1425-32.

Brethour, J. R. (2000) Using serial ultrasound measures to generate models of marbling and backfat thickness changes in feedlot cattle. Journal of Animal Science, 78, 2055-61.

Bruns, K. W., Pritchard, R. H. and Boggs, D. L. (2004) The relationships among body weight, body composition, and intramuscular fat content in steers. Journal of Animal Science, 82, 1315-22.

Busk, H. (1984) Improved Danscanner for cattle, pigs and sheep. In Lister, D. (ed.), In vivo Measurement of Body Composition in Meat Animals. London: Elsevier, 158-62.

Busk, H. (1986) Measure carcass quality on live pigs. World Review of Animal Production, 22, 35-8.

Campbell, D., Stonaker, H. H. and Esplin, A. L. (1959) The use of ultrasonics to estimate the size of longissimus dorsi muscle in sheep. Journal of Animal Science,24, 364-7.

Castellini, C., Dal Bosco, A. and Cardinali, R. (2006) Long term effect of post-weaning rhythm on the body fat and performance of rabbit doe. Reproduction Nutrition Development, 46, 195-204.

Chambaz, A., Dufey, P. A., Kreuzer, M. and Gresham, J. (2002) Sources of variation influencing the use of realtime ultrasound to predict intramuscular fat in live beef cattle. Canadian Journal of Animal Science, 82, 133-9.

Chen, C. H. (2007) Ultrasonic and advanced methods for non-destructive testing and material characterization. PhD Thesis, University of Massachusetts, Dartmouth.

Claus, A. (1957) The measurement of natural interfaces in the pig's body with ultrasound. Fleischwirtschaft, 9, 552-7.

Collewet, G., Toussaint, C., Davenel, A., Akoka, S., Médale, F., Fauconneau, B. and Haffray, P. (2001) Magnetic resonance imaging as a tool to quantify the adiposity distribution in fish. In Webb, G. A., Belton, P. S., Gil, V. and Delgadillo, I. (eds), Magnetic Resonance in Food Science. Cambridge: Royal Society of Chemistry, 252-7. 
Couto, P., Silva, S. R., Barrenechea, E., Santos, V. and Melo-Pinto, A. (2011) Fuzzy based subcutaneous fat assessment in real-time ultrasound images. Proceedings of the European Society for Fuzzy Logic and Technology, Aix-les-Bains, France, 350-7.

Crepaldi, D. V., Teixeira, A. E., Faria, P. M. C., Ribeiro, P. L., Melo, S. H., Daniela, M., Sousa, A. B. and Carvalho, D. C. (2006) Ultrasonography in fish culture (in Portuguese). Rev Bras Reprod Anim, 30, 174-81.

Dal Bosco, A., Castellini, C. and Mugnai, C. (2003) Evaluation of body condition in pregnant rabbit does by ultrasound scanner. Proceedings of the ASPA, Parma, Italy, 480-2.

Davenel, A., Seigneurin, F., Collewet, G. and Reamignon, H. (2000) Estimation of poultry breast meat yield: magnetic resonance imaging as a tool to improve the positioning of ultrasonic scanners. Meat Science, 56, 153-8.

Davis, J. K., Long, R. A., Saffe, R. L., Warren, E. P. and Carmon, J. L. (1964) Use of ultrasonics and visual appraisal to estimate total muscling in beef cattle. Journal of Animal Science, 23, 638-44.

De Campeneere, S., Fiems, L. O. and Boucqué, C. V. (2000) In vivo estimation of body composition in cattle. Nutrition Abstracts \& Reviews, 70, 495-508.

Delehant, T. M., Dahlke, G. R., Hoffman, M. P., Iiams, J. C., Rouse, G. H. and Wilson, D. E. (1996) Using real-time ultrasound during the feeding period to predict cattle composition. Beef Research Report AS Leaflet R1433, Iowa State University.

Delfa, R., Teixeira, A., Blasco, I. and Colomer-Rocher, F. (1991) Ultrasonics estimates of fat thickness, c measurement and longissimus dorsi depth in rasa Aragonesa ewes with same body condition score. Options Mèditerranéennes, 13, 25-30.

Delfa, R., Teixeira, A., Gonzalez, C. and Blasco, A. (1995a) Ultrasonic estimates of fat thickness and longissimus dorsi muscle depth for predicting carcass composition of live aragon lambs. Small Ruminant Research, 16, 159-64.

Delfa, R., Teixeira, A. and González, C. (1995b) Ultrasonic measurements of fat thickness and longissimus dorsi depth for predicting carcass composition and body fat depots of live goats. Proceedings of the 46th Annual Meeting of the EAAP, Prague, Czech Republic, 276.

Delfa, R., Gonzalez, A. T. C. and Vijil, E. (1996) Ultrasonic measurements in live goats prediction of weight of carcass joints. Proceedings of the 47th Annual Meeting of the EAAP, Lillehammer, Norway, 272.

Delfa, R., Teixeira, A., Cadavez, V., Gonzalez, C. and Sierra, I. (2000) Relationships between ultrasonic measurements in live goats and the same measurements taken on carcass. Proceedings of the 7th International Conference Goats, Tours, France, 833-4.

Devitt, C. and Wilton, J. (2001) Genetic correlation estimates between ultrasound measurements on yearling bulls and carcass measurements on finished steers. Journal of Animal Science, 79, 2790-7.

Dixson, S. J. and Teeter, R. G. (2001) Fast heat production and body composition of broiler breeder females ranging from 5 to 50 weeks of age. Animal Science Research Report P986, Oklahoma Agricultural Experiment Station, Oklahoma.

Dolezal, H. G., Smith, G. C., Savell, J. W. and Carpenter, Z. L. (1982) Comparison of subcutaneous fat thickness, marbling and quality grade for predicting palatability of beef. Journal of Food Science, 47, 397-401.

Du, C. J., Sun, D. W., Jackman, P. and Allen, P. (2008) Development of a hybrid image processing algorithm for automatic evaluation of intramuscular fat content in beef M. longissimus dorsi. Meat Science, 80, 1231-7.

Duclos, M. J., Molette, C., Guernec, A. and Berri, H. R. C. (2006) Cellular aspects of breast muscle development in chicken with high or low growth rate. Arch Tierernahr, 49, 147-51.

Dumont, B. L. (1957) Nouvelles methods pour l'estimation de la qualite des carcasses sur les porcs vivants. Joint Food and Agriculture Organization of the United Nations/EAAP, Meeting on Pig Progeny Testing, Copenhagen, Denmark, 23. 
DuPonte, M. W. and Fergerstrom, M. L. (2006) Application of ultrasound technology in beef cattle carcass research and management: Frequently asked questions. Livestock Management, 13, 1-3.

Dussik, K. T. (1942) Ube die moglichkeit hochfrecluente mechanische Schwingungen als diagnostiches Hilfsmittel zu verwenden. Z Gesamte Neurol Psychiatr, 174, 153-68.

Emenheiser, J. C., Greiner, S. P., Lewis, R. M. and Notter, D. R. (2010) Longitudinal changes in ultrasonic measurements of body composition during growth in Suffolk ram lambs and evaluation of alternative adjustment strategies for ultrasonic scan data. Journal of Animal Science, 88, 1341-8.

FAOSTAT (2010) Available from: http://faostatfaoorg/site/291/defaultaspx (accessed 6 May 2011).

Faucitano, L., Huff, P., Teuscher, F., Gariepy, C. and Wegner, J. (2005) Application of computer image analysis to measure pork marbling characteristics. Meat Science, 69 , 537-43.

Faulkner, D. B., McKeith, F. K., Berger, L. L., Kesler, D. J. and Parrett, D. F. (1989) Effect of testosterone propionate on performance and carcass characteristics of heifers and cows. Journal of Animal Science, 67, 1907.

Ferguson, D. M. (2004) Objective on-line assessment of marbling: a brief review. Australian Journal of Experimental Agriculture, 44, 681-5.

Fernández, C., Gallego, L. and Quintanilla, A. (1997) Lamb fat thickness and longissimus muscle area measured by a computerized ultrasonic system. Small Ruminant Research, 26, 277-82.

Fortun-Lamothe, L., Lamboley-Gaüzère, B. and Bannelier, C. (2002) Prediction of body composition in rabbit females using total body electrical conductivity (TOBEC). Livestock Production Science, 78, 133-42.

Fuller, M. F., Fowler, P. A., McNeill, G. and Foster, M. A. (1990) Body composition: the precision and accuracy of new methods and their suitability for longitudinal studies. Proceedings of the Nutrition Society, 49, 423-36.

Fuller, M. F., Fowler, P. A., McNeill, G. and Foster, M. A. (1994) Imaging techniques for the assessment of body composition. Journal of Nutrition, 124, 1546S-1550S.

Gibson, J. P. and Alliston, A. C. (1983) Some sources of errors and possible bias in Danscan ultrasonic measurements of cattle. Journal of Animal Production, 37, 61-71.

Glasbey, C. A., Abdalla, I. and Simm, G. (1996) Towards automatic interpretation of sheep ultrasound scans. Animal Science, 62, 309-15.

Goddard, P. R.(1995) General principles. In Goddard, P. J.(ed.), Veterinary Ultrasonography. Wallingford: CAB International, 1-19.

Gondret, F., Larzul, C., Combes, S. and Rochambeau, H. (2005) Carcass composition, bone mechanical properties, and meat quality traits in relation to growth rate in rabbits. Journal of Animal Science, 83, 1526-35.

Gooden, J. M., Beach, A. D. and Purchas, R. W. (1980) Measurements of subcutaneous backfat depth in live lambs with an ultrasonic probe. New Zealand Journal of Agricultural Research, 23, 161-5.

Grashorn, M. A. (2010) Research into poultry meat quality. British Poultry Science, 51, $60-7$.

Green, R. D., Field, T. G., Hammett, N. S., Ripley, B. M. and Doyle, S. P. (2000) Can cow adaptability and carcass acceptability both be achieved?. Journal of Animal Science, 77, $1-20$.

Greiner, S. P., Rouse, G. H., Wilson, D. E., Cundiff, L. V. and Wheeler, T. L. (2003) The relationship between ultrasound measurements and carcass fat thickness and longissimus muscle area in beef cattle. Journal of Animal Science, 81, 676-82.

Gresham, J. D., McPeake, S. R., Bernard, J. K. and Henderson, H. H. (1992) Commercial adaptation of ultrasonography to predict pork carcass composition from live animal and carcass measurements. Journal of Animal Science, 70, 631-9. 
Gresham, J. D., McPeake, S. R., Bernard, J. K., Riemann, M. J., Wyatt, R. W. and Henderson, H. H. (1994) Prediction of live and carcass characteristics of market hogs by use of a single longitudinal ultrasonic scan. Journal of Animal Science, 72, 1409-16.

Griffin, D. B., Savell, J. W., Recio, H. A., Garrett, R. P. and Cross, H. R. (1999) Predicting carcass composition of beef cattle using ultrasound technology. Journal of Animal Science, 77, 889-92.

Hamby, P. L., Stouffer, J. R. and Smith, S. B. (1986) Muscle metabolism and real-time ultrasound measurement of muscle and subcutaneous adipose tissue growth in lambs fed diets containing a beta-agonist. Journal of Animal Science, 63, 1410-17.

Hamlin, K. E., Green, R. D., Cundiff, L. V., Wheeler, T. L. and Dikeman, M. E. (1995) Real-time ultrasonic measurement of fat thickness and longissimus muscle area: II Relationship between real-time ultrasound measures and carcass retail yield. Journal of Animal Science, 73, 1725-34.

Hancz, C., Romvári, R., Szabo, A., Molnár, T., Magyary, I. and Horn, P. (2003) Measurement of total body composition changes of common carp by computer tomography. Aquaculture Research, 34, 1-7.

Harada, H. and Kumazaki, K. (1979) Estimating fat thickness, cross sectional area of M. Log. Thoracis and marbling score by use of ultrasonic scanning scope on live beef cattle. Japan Journal of Zoological Science, 50, 305-9.

Harron, W. and Dony, R. (2009) Predicting quality measures in beef cattle using ultrasound imaging more options. IEEE Symposium on Computational Intelligence for Image Processing, 96-103.

Hassen, A., Wilson, D. E., Willham, R. L., Rouse, G. H. and Trenkle, A. H. (1998) Evaluation of ultrasound measurements of fat thickness and longissimus muscle area in feedlot cattle: Assessment of accuracy and repeatability. Canadian Journal of Animal Science, 78, 277-86.

Hassen, A., Wilson, D. E. and Rouse, G. H. (1999a) Evaluation of carcass, live, and realtime ultrasound measures in feedlot cattle: II Effects of different age end points on the accuracy of predicting the percentage of retail product, retail product weight, and hot carcass weight. Journal of Animal Science, 77, 283-90.

Hassen, A., Wilson, D., Amin, V. and Rouse, G. (1999b) Repeatability of ultrasound predicted percentage of intramuscular fat in feedlot cattle. Journal of Animal Science, 77, 1335-40.

Hassen, A., Wilson, D. E., Amin, V. R., Rouse, G. H. and Hays, C. L. (2001) Predicting percentage of intramuscular fat using two types of real-time ultrasound equipment. Journal of Animal Science, 73, 11-18.

Haumschild, D. J. and Carlson, D. L. (1983) An ultrasonic Bragg scattering technique for the quantitative characterisation of marbling in beef. Ultrasonics, 21, 226-33.

Hazel, L. N. and Kline, E. A. (1959) Ultrasonic measurements of fatness in swine. Journal of Animal Science, 18, 815-19.

Hedrick, H. B., Meyer, W. E., Alexander, M. A., Zobrisky, S. E. and Naumann, H. D. (1962) Estimation of rib-eye area and fat thickness of beef cattle with ultrasonics. Journal of Animal Science, 21, 362-5.

Henderson-Perry, S. C., Corah, L. R. and Perry, R. C. (1989) The use of ultrasound in cattle to estimate subcutaneous fat thickness and ribeye area. Journal of Animal Science, 67(Suppl 1), 433.

Hernández, P., Aliaga, S., Pla, M. and Blasco, A. (2004) The effect of selection for growth rate and slaughter age on carcass composition and meat quality traits in rabbits. Journal of Animal Science, 82, 3138-43.

Hernández, P., Ariño, B., Grimal, A. and Blasco, A. (2006) Comparison of carcass and meat characteristics of three rabbit lines selected for litter size or growth rate. Meat Science, 73, 645-50.

Herring, W. O., Miller, D. C., Bertrand, J. K. and Benyshek, L. L. (1994) Evaluation of machine, technician, and interpreter effects on ultrasonic measures of backfat and longissimus muscle area in beef cattle. Journal of Animal Science, 72, 2216-26. 
Herring, W., Kriese, L., Bertrand, K. and Crouch, J. (1998) Comparison of four realtime ultrasound systems that predict intramuscular fat in beef cattle. Journal of Animal Science, 76, 364-70.

Hopkins, D. L., Pirlot, K. L., Roberts, A. H. K. and Beattie, A. S. (1993) Changes in fat depths and muscle dimensions in growing lambs as measured by real-time ultrasound. Australian Journal of Experimental Agriculture, 33, 707-12.

Hopkins, D. L., Hall, D. G. and Luff, A. F. (1996) Lamb carcass. 3. Describing changes in carcasses of growing lambs using real-time ultrasound and the use of these measurements for estimating the yield of saleable meat. Australian Journal of Experimental Agriculture, 36, 37-43.

Hopkins, D. L., Stanley, D. F. and Ponnampalam, E. N. (2007) Relationship between real-time ultrasound and carcass measures and composition in heavy sheep. Australian Journal of Experimental Agriculture, 47, 1304-8.

Houghton, P. L. and Turlington, L. M. (1992) Application of ultrasound for feeding and finishing animals: A review. Journal of Animal Science, 70, 930-41.

Huff-Lonergan, E. T., Baas, T. J., Malek, M., Dekkers, J. C. M., Prusa, K. and Rothschild, M. F. (2002) Correlations among selected pork quality traits. Journal of Animal Science, 80, 617-27.

Insana, M. F. (2006) Ultrasonic imaging. In Akay, M. and Hoboken, N. J. (eds), Encyclopedia of Biomedical Engineering. New York: John Wiley and Sons, 3640-8.

Jackman, P., Sun, D.-W., Du, C.-J., Allen, P. and Downey, G. (2008) Prediction of beef eating quality from colour, marbling and wavelet texture features. Meat Science, 80, 1273-81.

Kallweit, E., Wesemeier, H. H., Smidt, D. and Baulain, U. (1994) Application of magneticresonance-measurements in animal research. Arch Tierernahr, 31, 105-20.

Kane, D., Grassi, W., Sturrock, R. and Balint, P. (2004) A brief history musculoskeletal ultrasound: From bats and ships to babies and hips. Rheumatology, 43, 931-3.

Kemp, J. D., Herring, W. O. and Kaiser, C. J. (2002) Genetic and environmental parameters for steer ultrasound and carcass traits. Journal of Animal Science, 80, 1489-96.

Kempster, A. J., Cuthbertson, A. and Owen, M. G. (1979) A comparison of four ultrasonic machines (Sonatest, Scanogram, Ilis observer, and Danscanner) for predicting the body composition of live pigs. Journal of Animal Production, 29, 175-81.

Kempster, A. J., Arnall, D., Alliston, J. C. and Barker, J. D. (1982) An evaluation of two ultrasonic machines (Scanogram and Danscanner) for predicting the body composition of live sheep. Journal of Animal Production, 34, 249-55.

Kim, N., Amin, V., Wilson, D., Rouse, G. and Upda, S. (1998) Ultrasound image texture analysis for characterizing intramuscular fat content of live beef cattle. Ultrasonic Imaging, 20, 191-205.

King, A. M. (2006) Development, advances and applications of diagnostic ultrasound in animals. Veterinary Journal, 171, 408-20.

Kleczek, K., Wawro, K., Wilkiewicz-Wawro, E., Makowski, W. and Konstan-Tynowicz, D. (2009) Relationships between breast muscle thickness measured by ultrasonography and meatiness and fatness in broiler chickens. Arch Tierernahr, 52, 538-45.

Klein, H. G. (1981) Are B-scanners' days numbered in abdominal diagnosis?. Diagnostic Imaging, 3, 10-11.

Kolstad, K., Vegusdal, A., Baeverfjord, G. and Einen, O. (2004) Quantification of fat deposits and fat distribution in Atlantic halibut (hippoglossus hippoglossus 1) using computerised x-ray tomography (CT). Aquaculture, 229, 255-64.

Konig, T., Grashorn, M. A. and Bessei, W. (1997) Estimation of breast meat yield in living broilers using b-scan sonography first report: Defining sites of measurement. Arch Gelugelkd, 61, 227-31.

Konig, T., Grashorn, M. A. and Bessei, W. (1998) Estimation of breast meat yield in living broilers using b-scan sonography second report: Accuracy of the method. Arch Gelugelkd, 62, 121-5. 
Korn, S. V., Baulain, U., Arnold, M. and Brade, W. (2005) Nutzung von magnet-resonanztomographie und ultraschall-technik zur bestimmung des schlachko-rperwertes beim schaf. Zuchtungskunde, 77, 382-93.

Kouba, M. and Sellier, P. (2011) A review of the factors influencing the development of intermuscular adipose tissue in the growing pig. Meat Science, 88, 213-20.

Kövér, G., Romvári, R., Horn, P., Jensen, E. B. J. F. and Sorensen, P. (1998a) In vivo assessment of breast muscle, abdominal fat and total fat volume in meat type chickens by magnetic resonance imaging. Acta Vet Hung, 46, 135-44.

Kövér, G., Szendrö, Z., Romvári, R., Jensen, J. F. and Milisits, G. (1998b) In vivo measurement of body parts and fat deposition in rabbits by MRI. World Rabbit Science, $\mathbf{6}$, 231-5.

Kvame, T. and Vangen, O. (2006) In vivo composition of carcass regions in lambs of two genetic lines, and selection of CT positions for estimation of each region. Small Ruminant Research, 66, 201-208.

Larivière, J. M., Michaux, C., Verleyen, V., Hanzen, C. and Leroy, P. (2009) Non-invasive methods to predict breast muscle weight in slow-growing chickens. International Journal of Poultry Science, 8, 689-91.

Larzul, C., Gondret, S., Combes, S. and Rochambeau, H. (2005) Divergent selection on 63-old body weight in the rabbit: Response on growth, carcass and muscle traits. Genetics Selection Evolution, 37, 105-22.

Latshaw, J. D. and Bishop, B. L. (2001) Estimating body weight and body composition of chickens by using noninvasive measurements. Poultry Science, 80, 868-73.

Leeds, T. D., Mousel, M. R., Notter, D. R. and Lewis, G. S. (2007) Ultrasound estimates of loin muscle measures and backfat thickness augment live animal prediction of weights of subprimal cuts in sheep. Proceedings, Western Section, American Society of Animal Science, 58, 97-100.

Leeds, T. D., Mousel, M. R., Notter, D. R., Zerby, H. N., Mollet, C. A. and Lewis, G. S. (2008) B-mode, real-time ultrasound for estimating carcass measures in live sheep: Accuracy of ultrasound measures and their relationships with carcass yield and value. Journal of Animal Science, 86, 3203-14.

Leighton, T. G. (2007) What is ultrasound? Progress in Biophysics and Molecular Biology, 93, 3-83.

Li, C. (2010) A web service model for conducting research in image processing. Journal of Computing in Small Colleges, 25, 294-9.

Li, C. C., Zheng, Y. F. and Kwabena, A. (2009) Prediction of IMF percentage of live cattle by using ultrasound technologies with high accuracies. In Qui, R. and Zhao, H. (eds), WASE International Conference on Information Engineering (ICIE 2009), II, 474-8.

Ludwig, G. D. (1950) The velocity of sound through tissues and the acoustic impedance of tissues. Journal of the Acoustical Society of America, 22, 862-6.

Lukefahr, S. D. and Ozimba, C. E. (1991) Prediction of carcass merit from live body measurements in rabbits of four breed-types. Livestock Production Science, 29, 323-34.

Lukefahr, S. D., Hohenboken, W. D., Cheeke, P. R., Patton, N. M. and Kennick, W. H. (1982) Carcass and meat characteristics of flemish giant and New Zealand white purebred and terminal-cross rabbits. Journal of Animal Science, 54, 1169-74.

Lukefahr, S. D., Hohenboken, W. D., Cheeke, P. R. and Patton, N. M. (1983) Appraisal of nine genetic groups of rabbits for carcass and lean yield traits. Journal of Animal Science, 57, 899-907.

Lusk, J. L., Little, R., Williams, A., Anderson, J. and McKinley, B. (2003) Utilizing ultrasound technology to improve livestock marketing decisions. Review of Agricultural Economics, 25, 203-17.

Lyons, E. (2004) Zone sonography: The next major advance in medical ultrasound. Winnipeg, University of Manitoba. Available from: http://www.radicansa.com/ radicansa1/images/pdf1/Zone_Sonography_Technology_Clinical_White_Paper.pdf (accessed 14 May 2011). 
Macfarlane, J. M. and Simm, G. (2008) Genetic improvement programme for meat type sheep: An experience from the United Kingdom. Tecnologia e Ciência Agropecuária, 2, 15-22.

MacNeil, M. D., Nkrumah, J. D., Woodward, B. W. and Northcutt, S. L. (2010) Genetic evaluation of angus cattle for carcass marbling using ultrasound and genomic indicators. Journal of Animal Science, 88, 517-22.

Mannion, P. (2006) Principles of diagnostic ultrasound. In Mannion, P. (ed.), Diagnostic Ultrasound in Small Animal Practice. Oxford: Blackwell, 1-19.

May, S. G., Miles, W. L., Edwards, J. W., Harris, J. J., Morgan, J. B., Garrett, R. P., Williams, F. L., Wise, J. W., Cross, H. R. and Savell, J. W. (2000) Using live estimates and ultrasound measurements to predict beef carcass cutability. Journal of Animal Science, 78, 1255-61.

McEwan, J. C., Clarke, J. N., Knowler, M. A. and Wheeler, M. (1989) Ultrasonic fat depths in romney lambs and hoggets from lines selected for different production traits. Proceedings of the New Zealand Society of Animal Production, 49, 113-19.

McLaren, D. G., McKeith, F. M. and Novakofski, J. (1989) Prediction of carcass characteristics at market weight from serial real-time ultrasound measures of backfat and loin eye area in the growing pig. Journal of Animal Science, 67, 1657-67.

McLaren, D. G., Novakofski, J., Parrett, D. F., Lo, L. L., Singh, S. D., Neumann, K. R. and McKeith, F. K. (1991) A study of operator effects on ultrasonic measures of fat depth and longissimus muscle area in cattle, sheep and pigs. Journal of Animal Science, 69, 54-66.

McPeake, C. A. (2001) USDA marbling and carcass physiological maturity related differences for beef tenderness and palatability characteristics. PhD Thesis, Oklahoma State University.

Melo, J. E., Motter, M. M., Morão, L. R., Huguet, M. J., Canet, Z. and Miquel, C. M. (2003) Use of in vivo measurements to estimate breast and abdominal fat content of a free-range broiler strain. Journal of Animal Science, 77, 23-31.

Mesta, C. G., Will, P. A. and Gonzalez, J. M. (2004) The measurement of carcass characteristics of goats using the ultrasound method. Texas Journal of Agriculture and Natural Resources, 17, 46-52.

Michalik, D., Bochno, R., Janiszewska, M. and Brzozowski, W. (1999) In vivo assessment of meatiness and fatness in broiler chickens using ultrasonography. Pr Mater Zootech, 54, 77-83.

Michalik, D., Lewczuk, A., Wilkiewicz-Wawro, E. and Brzozowski, W. (2006) Prediction of the meat content of the carcass and valuable carcass parts in French lop rabbits using some traits measured in vivo and post mortem. Czech Journal of Animal Science, 51, 406-15.

Miles, C. M., Pomeroy, R. W. and Harries, J. M. (1972) Some factories affecting reproductibility in ultrasonic scanning of animals. Journal of Animal Production, 15, 239-49.

Mitchell, A. D. and Scholz, A. M. (2005) Body composition: Indirect measurements. In Pond, W. and Bell, A. (eds), Encyclopedia of Animal Science. New York: Marcel Dekker, 166-9.

Mitchell, A. D., Wang, P. C., Rosebrough, R. W., Elsasser, T. H. and Schmidt, W. F. (1991) Assessment of body composition of poultry by nuclear magnetic resonance imaging and spectroscopy. Poultry Science, 70, 2494-500.

Mitchell, A. D., Rosebrough, R. W. and Conway, J. M. (1997) Body composition analysis of chickens by dual energy x-ray absorptiometry. Poultry Science, 76, 1746-52.

Mitchell, A. D., Scholz, A. M. D., Wange, P. C. and Song, H. (2001) Body composition analysis of the pig by magnetic resonance imaging. Journal of Animal Science, 79, 1800-13.

Moeller, S. J. (1990) Serial real-time ultrasonic evaluation of fat and muscle deposition in market hogs. PhD Thesis, Iowa State University.

Moeller, S. J. (2002) Evolution and use of ultrasonic technology in the swine industry. Journal of Animal Science, 80(E. Suppl 2), E19-E27. 
Moeller, S. J. and Christian, L. L. (1998) Evaluation of the accuracy of real-time ultrasonic measurements of backfat and loin muscle area in swine using multiple statistical analysis procedures. Journal of Animal Science, 76, 2503-14.

Monteiro, A. (2010) Methods to predict carcass composition of Serrana kids. PhD Thesis, University of Trás-os-Montes and Alto Douro, Vila Real, Portugal.

Monziols, M., Collewet, G., Bonneau, M., Mariette, F., Davenel, A. and Kouba, M. (2006) Quantification of muscle, subcutaneous fat and intermuscular fat in pig carcasses and cuts by magnetic resonance imaging. Meat Science, 72, 146-54.

Morlein, D., Rosner, F., Brand, S., Jenderka, K. V. and Wicke, M. (2005) Non-destructive estimation of the intramuscular fat content of the longissimus muscle of pigs by means of spectral analysis of ultrasound echo signals. Meat Science, 69, 187-99.

Nalaila, S. M., Stothard, P., Moore, S. S., Wang, Z. and Li, C. (2011) Whole genome fine mapping of quantitative trait loci for ultrasound and carcass merit traits in beef cattle. Canadian Journal of Animal Science, 91, 61-73.

Newcom, D. W., Baas, T. J. and Lampe, J. F. (2002) Prediction of intramuscular fat percentage in live swine using real-time ultrasound. Journal of Animal Science, 80, 3046-52.

O'Brien, R. T. and Holmes, S. P. (2007) Recent advances in ultrasound technology. Clinical Techniques in Small Animal Practice, 22, 93-103.

Oberle, M., Schwarz, F. J. and Kirchgessner, M. (1997) Growth and carcass quality of carp (cyprinus carpio 1) fed different cereals, lupin seed or zooplankton. Arch Tierernahr, 50, $75-86$.

Olsen, E. V., Candek-Potokar, M., Oksama, M., Kien, S., Lisiak, D. and Busk, H. (2007) On-line measurements in pig carcass classification: Repeatability and variation caused by the operator and the copy of instrument. Meat Science, 75, 29-38.

Ophir, J. and Maklad, N. (1979) Digital scan converters in diagnostic ultrasound imaging. IEEE Proceedings, 67, 654-64.

Orman, A., Calfskan, G. U., Dikmen, S., Ustuner, H., Ogan, M. and Caliskan, C. (2008) The assessment of carcass composition of Awassi male lambs by real- time ultrasound at two different live weights. Meat Science, 80, 1031-6.

Orman, A., Caliskan, G. U. and Dikmen, S. (2010) The assessment of carcass traits of Awassi lambs by real-time ultrasound at different body weights and sexes. Journal of Animal Science, 88, 3428-38.

Oviedo-Rondón, E. O., Parker, J. and Clemente-Hernández, S. (2007) Application of realtime ultrasound technology to estimate in vivo breast muscle weight of broiler chickens. British Poultry Science, 48, 151-61.

Paisley, S., Loehr, C. and Niemela, F. (2007) Ultrasound-based selection: Pitfalls and rewards. Proceedings of the Range of Beef Cow Symposium XX Fort Collins, Colorado.

Parnell, P. F. (2004) Industry application of marbling genetics: A brief review. Australian Journal of Experimental Agriculture, 44, 697-703.

Pascual, J. J., Castella, F., Cervera, C., Blas, E. and Fernández-Carmona, J. (2000) The use of ultrasound measurement of perirenal fat thickness to estimate changes in body condition of young female rabbits. Animal Science, 70, 435-42.

Pascual, J. J., Motta, W., Cervera, C., Quevedo, F., Blas, E. and Fernández-Carmona, J. (2002) Effect of dietary energy source on the performance and perirenal fat thickness evolution of primiparous rabbit does. Animal Science, 75, 267-73.

Pascual, J. J., Blanco, J., Piquer, O., Quevedo, F. and Cervera, C. (2004) Ultrasound measurements of perirenal fat thickness to estimate the body condition of reproducing rabbit does in different physiological status. World Rabbit Science, 12, 7-22.

Pascual, M. and Pla, M. (2007) Changes in carcass composition and meat quality when selecting rabbits for growth rate. Meat Science, 77, 474-81.

Perkins, T. L., Green, R. D. and Hamlin, K. E. (1992a) Evaluation of ultrasonic estimates of carcass fat thickness and longissimus muscle area in beef cattle. Journal of Animal Science, 70, 1002-10. 
Perkins, T. L., Green, R. D., Hamlin, K. E., Shepard, H. H. and Miller, M. F. (1992b) Ultrasonic prediction of carcass merit in beef cattle: evaluation of technician effects on ultrasonic estimates of carcass fat thickness and longissimus muscle area. Journal of Animal Science, 70, 2758-65.

Pethick, D. W., Harper, G. S., Hocquette, J. F. and Wang, Y. (2006) Marbling biology - what do we know about getting fat into muscle? Proceedings of Australian beef the leader! The Impact of Science on the Beef Industry, University of New England, Armidale, NSW, 103-10.

Peura, A. R. and Webster, J. G. (1998) Basic sensors and principles. In Webster, J. G. (ed.), Medical Instrumentation: Application and Design. New York: John Wiley and Sons, 45-90.

Prince, J. L. and Links, J. M. (2006) Medical Imaging Signals and Systems. New Jersey: Pearson Prentice Hall.

Probert, P. and Shannon, R. (2000) Wideband ultrasound to determine lipid concentration in fish. In Halliwell, M. and Wells, P. N. T. (eds), Acoustical Imaging. Oxford: Springer, 381-8.

Pyatt, N. A., Berger, L. L., Faulkner, D. B., Walker, P. M. and Rodriguez-Zas, S. L. (2005) Factors affecting carcass value and profitability in early-weaned Simmental steers: II. Days on feed endpoints and sorting strategies. Journal of Animal Science, 83, 2926-37.

Quevedo, F., Cervera, C., Blas, E., Baselga, M. and Pascual, J. J. (2006) Long-term effect of selection for litter size and feeding programme on the performance of reproductive rabbit does. 1. Pregnancy of multiparous does. Journal of Animal Science, 82, 739-50.

Raeth, U., Schlaps, D., Limberg, B., Zum, I., Lorenz, A., van Kaick, G., Lorenz, W. T. and Kommerell, B. (1985) Diagnostic accuracy of computerized b-scan texture analysis and conventional ultrasonography in diffuse parenchymal and malignant liver disease. Journal of Clinical Ultrasound, 13, 87-9.

Ragland, K. D., Christian, L. L. and Baas, T. J. (1997) Evaluation of real-time ultrasound and carcass characteristics for assessing carcass composition in swine. Beef Research Report AS Leaflet R1424, Iowa State University.

Ramsey, C. B., Kirton, A. H., Hogg, B. and Dobbie, J. L. (1991) Ultrasonics, needle and carcass measurements for predicting chemical composition of lamb carcasses. Journal of Animal Science, 69, 3655-64.

Rémignon, H., Seigneurin, F. and Moati, F. (2000) In vivo assessment of the quality of breast muscle by sonography in broilers. Meat Science, 56, 133-8.

Renand, G., Larzul, C., Le Bihan-Duval, E. and Le Roy, P. (2003) Genetic improvement of meat quality in the different livestock species: Present situation and prospects. Productions Animales, 16, 159-73.

Rimal, A., Perkins, T. and Paschal, J. C. (2006) Ultrasound technology for better beef price. Acta Agriculturae Scandinavica C, 3, 99-104.

Ripoll, G., Joy, M., Alvarez-Rodriguez, J., Sanz, A. and Teixeira, A. (2009) Estimation of light lamb carcass composition by in vivo real-time ultrasonography at four anatomical locations. Journal of Animal Science, 87, 1455-63.

Ripoll, G., Joy, M. and Sanz, A. (2010) Estimation of carcass composition by ultrasound measurements in 4 anatomical locations of 3 commercial categories of lamb. Journal of Animal Science, 88, 3409-18.

Robinson, D. L., McDonald, C. A., Hammond, K. and Turner, J. W. (1992) Live animal measurement of carcass traits by ultrasound: Assessment and accuracy of sonographers. Journal of Animal Science, 70, 1667-76.

Rodrigues, V., Dias, J., Rema, P. and Silva, S. R. (2010) Mapping body fat distribution in farmed senegalese sole (solea senegalensis). Proceedings of EAS Aquaculture Europe, World Aquaculture Society, Porto, Portugal, 1120-1. 
Romvári, R., Hancz, C. S., Petrási, Z. S., Molnár, T. and Horn, P. (2002) Non-invasive measurement of fillet composition of four freshwater fish species by computer tomography. Aquaculture International, 10, 231-40.

Romvári, R., Milisits, G., Szendrö, Z. and Sorensen, P. (1996) Non invasive method to study the body composition of rabbits by x-ray computerised tomography. World Rabbit Science, 4, 219-24.

Rymkiewicz, J. and Bochno, B. R. (1999) Estimation of breast muscle weight in chickens on the basis of live measurements. Arch Gefluelkd, 63, 229-33.

Sañudo, C., Enser, E., Nute, M. C. R., Maria, G., Sierra, I. and Wood, J. D. (2000) Fatty acid composition and sensory characteristics of lamb carcasses from Britain and Spain. Meat Science, 54, 339-46.

Sather, A. P., Bailey, D. R. C. and Jones, S. D. M. (1996) Real-time ultrasound image analysis for estimation of carcass yield and pork quality. Canadian Journal of Animal Science, 76, 55-62.

Savell, J. W., Cross, H. R., and Smith, G. C. (1986) Percentage ether extractable fat and moisture content of beef longissimus muscle as related to USDA marbling score. Journal of Food Science, 51, 838-9.

Schröder, U. J. and Staufenbiel, R. (2006) Invited review: Methods to determine body fat reserves in the dairy cow with special regard to ultrasonographic measurement of backfat thickness. Journal of Dairy Science, 89, 1-14.

Schwab, C. R., Baas, T. J., Stalder, K. J. and Nettleton, D. (2009) Results from six generations of selection for intramuscular fat in duroc swine using real-time ultrasound. I. Direct and correlated phenotypic responses to selection. Journal of Animal Science, 87, 2774-80.

Schwab, C. R., Baas, T. J. and Stalder, K. J. (2010) Results from six generations of selection for intramuscular fat in duroc swine using real-time ultrasound. II. Genetic parameters and trends. Journal of Animal Science, 88, 69-79.

Scollan, N. D., Caston, L. J., Liu, Z., Zubair, A. K., Leeson, S. and McBrid, B. W. (1998) Nuclear magnetic resonance imaging as a tool to estimate the mass of the pectoralis muscle of chickens in vivo. British Poultry Science, 39, 221-4.

Seidband, M. P. (1998) Medical imaging systems. In Webster, J. G. (ed.), Medical Instrumentation: Application and Design. New York: John Wiley and Sons, 518-76.

Shelton, M., Smith, G. C. and Orts, F. (1977) Predicting carcass cutability of Rambouillet rams using live animal traits. Journal of Animal Science, 44, 333-7.

Shi-Zheng, G. and Su-Mei, Z. (2009) Physiology, affecting factors and strategies for control of pig meat intramuscular fat. Recent Patents on Food Nutrition \& Agriculture, 1 , $59-74$.

Sigfusson, H., Decker, E. A. and McClements, D. J. (2000) Rapid prediction of Atlantic mackerel (scomber scombrus) composition using a hand-held ultrasonic device. Journal of Aquatic Food Production and Technology, 9, 27-38.

Silva, S. L., Leme, P. R., Putrino, S. M., Martello, L. S., Lima, C. G. and Lanna, D. P. D. (2004) Prediction of backfat at slaughter, by ultrasound, in Nellore and Brangus young bulls. Revista Brasileira de Zootecnia, 33, 511-17.

Silva, S. R., Gomes, M. J., Dias-da-Silva, A. and Azevedo, J. M. T. (2005) Estimation in vivo of the body and the carcass chemical composition of growing lambs by real-time ultrasonography. Journal of Animal Science, 83, 350-7.

Silva, S. R., Afonso, J. J., Santos, V. A., Monteiro, A., Guedes, C. M., Azevedo, J. M. T. and Dias-da-Silva, A. (2006a) In vivo estimation of sheep carcass composition using real-time ultrasound with two probes of 5 and $75 \mathrm{MHz}$ and image analysis. Journal of Animal Science, 84, 3433-9.

Silva, S. R., Pinheiro, V. M., Guedes, C. M. and Mourão, J. L. (2006b) Prediction of carcass and breast weights and yields in broiler chickens using breast volume determined in vivo by real-time ultrasonic measurement. British Poultry Science, 46, 1-6. 
Silva, S. R., Guedes, C. M., Santos, V. A., Lourenço, A. L., Azevedo, J. M. T. and Diasda-Silva, A. (2007a) Sheep carcass composition estimated from longissimus thoracis et lumborum muscle volume measured by in vivo real-time ultrasonography. Meat Science, 76, 708-14.

Silva, S. R., Guedes, C. M., Mourão, J. and Pinheiro, V. (2007b) Rabbit carcass chemical composition predicted by real-time ultrasonography. Proceedings of the XXXII Symposium de ASESCU, Vila Real, Portugal, 9-12.

Silva, S. R., Mourão, J. L., Guedes, C. M., Pio, A. and Pinheiro, V. (2008a) In vivo rabbit carcass composition and longissimus dorsi muscle volume prediction by realtime ultrasonography. Proceedings of the 9th World Rabbit Congress, Verona, Italy, 1449-53.

Silva, S. R., Guedes, C. M., Mourão, J. L., Venâncio, C. and Pinheiro, V. (2008b) Estimation of rabbit hind leg muscle weight and muscularity by real-time ultrasonography. Proceedings of the 9th World Rabbit Congress. Verona, Italy, 1443-7.

Silva, S. R., Mourão, J. L., Pio, A. and Pinheiro, V. M. (2009) The value of in vivo real-time ultrasonography in assessing loin muscularity and carcass composition of rabbits. Meat Science, 81, 357-63.

Silva, S. R., Guedes, C. M., Loureiro, N., Mena, E., Dias, J. and Rema, P. (2010a) Prediction in vivo of the fillet volume in senegalese sole (solea senegalensis) by multiple consecutive transverse real-time ultrasonography images, Proceedings of the 6th International Conference on Simulation and Modelling in the Food and Bio-industry, Bragança, Portugal, 219-23.

Silva, S. R., Patrício, M., Guedes, C. M., Mena, E., Silva, A. and Jorge, V. S. A. (2010b) Assessment of muscle longissimus thoracis et lumborum intramuscular fat by ultrasonography and image analysis. Proceedings of the 6th International Conference on Simulation and Modelling in the Food and Bio-industry, Bragança, Portugal, 211-15.

Simm, G. (1983) The use of ultrasound to predict the carcass composition of live cattle - a review. Animal Breeding Abstracts, 51, 853-75.

Simm, G. (1987) Carcass evaluation in sheep breeding programmes. In Marai, I. F. and Owen, J. F. (eds), New Techniques in Sheep Production. London: Butterworth, 125-44.

Simm, G., Alliston, J. C. and Sutherland, R. A. (1983) Comparison of live animal measurements for selecting lean beef sires. Journal of Animal Production, 37, 211-19.

Simm, G., Lewis, R. M., Grundy, B. and Dingwall, W. S. (2002) Responses to selection for lean growth in sheep. Journal of Animal Science, 74, 39-50.

Skiba, G. (2010) Effects of energy or protein restriction followed by re-alimentation on the composition of gain and meat quality characteristics of musculus longissimus dorsi in pigs. Archives of Animal Nutrition, 64, 36-46.

Smith, G. C., Tatum, J. D. and Belk, K. E. (2008a) International perspective: characterisation of united states department of agriculture and meat standards Australia systems will be assessing beef quality. Australian Journal of Experimental Agriculture, 48, 1465-80.

Smith, L., Perron, A., Persico, A., Stravinskas, E. and Cournoyea, D. (2008b) Enhancing image quality using advanced signal processing techniques. Journal of Diagnostic Medical Sonography, 24, 72-81.

Smith, M. T., Oltjen, J. W., Dolezal, H. G., Gill, D. R. and Behrens, B. D. (1992) Evaluation of ultrasound for prediction of carcass fat thickness and longissimus muscle area in feedlot steers. Journal of Animal Science, 70, 29-37.

Spangler, M. L. and Moser, D. W. (2009) Real-time ultrasound: What does image quality mean to genetic evaluations?. Proceedings of the Beef Improvement Federation 41st Annual Research Symposium, Sacramento, California, 145-50.

Stanford, K., Clark, I. and Jones, S. D. M. (1995a) Use of ultrasound in prediction of carcass characteristics in lambs. Canadian Journal of Animal Science, 75, 185-9. 
Stanford, K., McAllister, T. A., McDougall, M. and Bailey, D. R. C. (1995b) Use of ultrasound for prediction of carcass characteristics in Alpine goats. Small Ruminant Research, 15, 195-201.

Stanford, K., Jones, S. D. M. and Price, M. A. (1998) Methods of predicting lamb carcass composition: A review. Small Ruminant Research, 29, 241-54.

Stouffer, J. R. (1959) Status of the application of ultrasonics in meat animal evaluation. Proceedings of the Reciprocal Meat Conference, 12, 161-9.

Stouffer, J. R. (1991) Using ultrasound to objectively evaluate composition and quality of livestock. 21st Century Concepts Important to Meat-Animal Evaluation, University of Wisconsin, Madison, 49-54.

Stouffer, J. R. (2004) History of ultrasound in animal science. Journal of Ultrasound in Medicine, 23, 577-84.

Stouffer, J. R., Wallentine, M. V., Wellington, G. H. and Diekmann, A. (1961) Development and application of ultrasonic methods for measuring fat thickness and rib-eye area in cattle and hogs. Journal of Animal Science, 20, 759-67.

Suguisawa, L., Mattos, W. R. S., Oliveira, H. N., Silveira, A. C., Arrigoni, M. B., Haddad, C. M., Chardulo, L. A. L. and Martins, C. L. (2003) Ultrasonography as a predicting tool for carcass traits of young bulls. Scientia Agricola, 60, 779-84.

Suvanich, V., Ghaedian, R., Chanamai, R., Decker, E. A. and McClements, D. J. (1998) Prediction of proximate fish composition from ultrasonic properties: Catfish, cod, flounder, mackerel and salmon. Journal of Food Science, 63, 966-8.

Svihus, B. and Katle, J. (1993) Computerised tomography as a tool to predict composition traits in broilers comparisons of results across samples and years. Acta Agriculturae Scandinavica A, 43, 214-18.

Swennen, Q., Janssens, G. P. J., Geers, R., Decuypere, E. and Buyse, J. (2004) Validation of dual-energy x-ray absorptiometry for determining in vivo body composition of chickens. Poultry Science, 83, 1348-57.

Szabo, C., Babinszky, L., Verstegen, M. W. A., Vangen, O., Jansman, A. J. M. and Kanis, E. (1999) The application of digital imaging techniques in the in vivo estimation of body composition of pigs: A review. Livestock Production Science, 60, 1-11.

Szabo ,T .L. (2004) Diagnostic Ultrasound Imaging: Inside Out. Connecticut: Academic Press Series in Biomedical Engineering.

Szendrö, Z., Horn, P., Kövér, G., Berenyl, E., Radnai, I. and Biróné-Németh, E. (1992) In vivo measurement of the carcass traits of meat type rabbits by x-ray computerised tomography. Journal of Applied Rabbit Research, 15, 799-809.

Szendrö, Z., Metzger, S., Romvári, R., Szabó, A., Locsmándi, L., Petrási, Z., Nagy, I., Nagy, Z., Biró-Németh, E., Radnai, I., Matics, Z. and Horn, P. (2008) Effect of divergent selection based on CT measured hind leg muscle volume on productive and carcass traits of rabbits. Proceedings of the 9th World Rabbit Congress, Verona, Italy, 249-53.

Teixeira, A. (2009) Basic composition: Rapid methodologies. In Nollet, L. M. L. and Toldra, F. (eds), Handbook of Muscle Foods Analysis. Boca Raton,FL: CRC, Taylor and Francis Group, 291-314.

Teixeira, A., Matos, S., Rodrigues, S., Delfa, R. and Cadavez, V. (2006) In vivo estimation of lamb carcass composition by real-time ultrasonography. Meat Science, 74, $289-95$.

Teixeira, A., Joy, M. and Delfa, R. (2008) In vivo estimation of goat carcass composition and body fat partition by real-time ultrasonography. Journal of Animal Science, 86, 2369-76.

Temple, R. S., Stonaker, H. H., Howry, D., Posakony, G. and Hazaleus, M. H. (1956) Ultrasonic and conductivity methods for estimating fat thickness in live cattle. Proceedings, Western Section, American Society of Animal Science, 7, 477-81.

Terry, C. A., Savell, J. W., Recio, H. A. and Cross, H. R. (1989) Using ultrasound technology to predict pork carcass composition. Journal of Animal Science, 67, 1279-2884.

Thériault, M., Pomar, C. and Castonguay, F. (2009) Accuracy of real-time ultrasound measurements of total tissue, fat, and muscle depths at different measuring sites in lamb. Journal of Animal Science, 87, 1801-13. 
Thompson, J. M. (2004) The effects of marbling on flavour and juiciness scores of cooked beef, after adjusting to a constant tenderness. Australian Journal of Experimental Agriculture, 44, 645-52.

Thompson, M. R. (2010) The future of portable ultrasound: Business strategies for survival. MSc Thesis of Science in engineering and management, Massachusetts Institute of Technology.

Thwaites, C. J. (1984) Ultrasonic estimation of carcass composition - a review. Australian Meat Research Committee, 47, 1-32.

Trenkle, A. H. and Williams, J. C. (1997) Potential value of ultrasound to sort feeder cattle into more uniform groups for finishing and marketing, Beef Research Report AS Leaflet $R 1432$, Iowa State University.

Tume, R. K. (2004) The effects of environmental factors on fatty acid composition and the assessment of marbling in beef cattle: A review. Australian Journal of Experimental Agriculture, 44, 663-8.

Turner, R. C., Fuierer, P. A., Newnham, R. E. and Shrout, T. R. (1994) Materials for high temperature acoustic and vibration sensors: A review. Applied Acoustic, 41, 299-324.

Veliyulin, E., Zwaag, C., Burk, W. and Erikson, U. (2005) In vivo determination of fat content in Atlantic salmon (salmo salar) with a mobile NMR spectrometer. Journal of the Science of Food and Agriculture, 85, 1299-304.

Wall, P. B., Rouse, G. H., Wilson, D. E., Tait Jr, R. G. and Busby, W. D. (2004) Use of ultrasound to predict body composition changes in steers at 100 and 65 days before slaughter. Journal of Animal Science, 82, 1621-9.

Weinstein, S. P., Conant, E. F. and Chadra, S. (2006) Technical advances in breast ultrasound imaging seminars in ultrasound imaging. Seminars in Ultrasound CT and MRI, 27, 273-83.

Wells, P. N. T. (1991) The description of animal form and function. Livestock Production Science, 27, 19-33.

Wells, P. N. T. (2000) Current status and future technical advances of ultrasonic imaging. IEEE Engineering in Medicine and Biology, 19, 14-20.

Wells, P. N. T. (2006) Ultrasound imaging. Physics in Medicine and Biology, 51, R83-R98.

Whitsett, C. M. (2009) Ultrasound imaging and advances in system features. Ultrasound Clinics, 4, 391-401.

Whittaker, A. D., Park, B., Thane, B. R., Miller, R. K. and Savell, J. W. (1992) Principles of ultrasound and measurement of intramuscular fat. Journal of Animal Science, 70, 942-52.

Wild, J. J. (1950) The use of ultrasonic pulses for the measurement of biologic tissues and the detection of tissue density changes. Surgery, 27, 183-8.

Wild, J. J. and Reid, J. M. (1952) Application of echo-ranging techniques to the determination of structure of biological tissues. Science, 115, 226-30.

Williams, A. R. (2002) Ultrasound applications in beef cattle carcass research and management. Journal of Animal Science, 80 (E-Suppl 2), E183-E188.

Williams, R. E. and Trenkle, A. (1997) Sorting feedlot steers using ultrasound estimates of backfat at the 12th and 13th rib prior to the finishing phase. Journal of Animal Science, 75(Suppl 1), 55.

Wilson, D. E. (1992) Application of ultrasound for genetic improvement. Journal of Animal Science, 70, 973-83.

Wold, J. P. and Isaksson, T. (1997) Nondestructive determination of fat and moisture in whole Atlantic salmon by near-infrared diffuse spectroscopy. Journal of Food Science, 62, 734-6.

Woo, J. D. (2006) A short history of the development of ultrasound in obstetrics and gynecology. Available from: http://www.ob-ultrasound.net/history1.html (accessed 6 March 2011). 
Wood, J. D. (1990) Consequences for meat quality of reducing carcass fatness. In Wood, J. D. and Fisher, A. V. (eds), Reducing Fat in Meat Animals. London: Elsevier, 344-97.

Wood, J. D. (1995) The influence of carcass composition on meat quality. In Jones, S. M. (ed.), Quality and Grading of Carcasses of Meat Animals, Boca Raton, FL: CRC Press, 131-55.

Wood, J. V., Enser, M., Fisher, A. V., Nute, G. R., Sheard, P. R., Richardson, R. I., Hughes, S. I. and Whittington, F. M. (2008) Fat deposition, fatty acid composition and meat quality: A review. Meat Science, 78, 343-58.

Young, M. J. and Deaker, J. M. (1994) Ultrasound measurements predict estimated adipose and muscle weights better than carcass measurements. Proceedings of the New Zealand Society of Animal Production, 54, 215-17.

Young, M. J., Deaker, J. M. and Logan, C. M. (1992) Factors affecting repeatability of tissue depth determination by real-time ultrasound in sheep. Proceedings of the New Zealand Society of Animal Production, 52, 37-9.

Zerehdaran, S., Vereijken, A. L. J., van Arendonk, J. A. M., Bovenhuis, H. and van der Waaij, E. H. (2005) Broiler breeding strategies using indirect carcass measurements. Poultry Science, 84, 1214-21. 